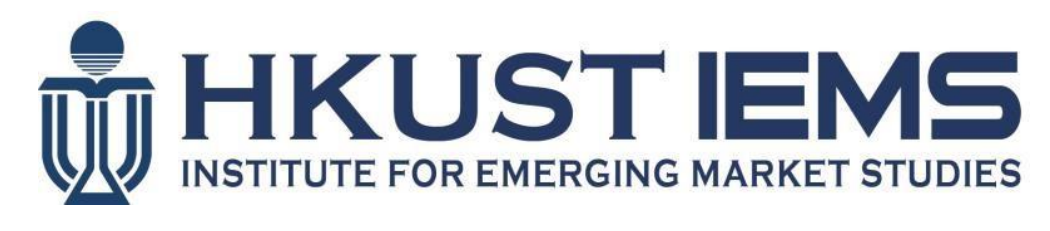

\title{
Regulation of Al Technologies in the Construction Industry
}

\author{
Vishnu SIVARUDRAN PILLAI, Kira MATUS
}

HKUST IEMS Working Paper No. 2019-65

\begin{abstract}
HKUST IEMS working papers are distributed for discussion and comment purposes. The views expressed in these papers are those of the authors and do not necessarily represent the views of HKUST IEMS.
\end{abstract}




\title{
Regulation of Al Technologies in the Construction Industry
}

\author{
Vishnu SIVARUDRAN PILLAI, Kira MATUS \\ HKUST IEMS Working Paper No. 2019-65
}

\begin{abstract}
The development of Artificial Intelligence (Al) -based technologies for the construction industry, though not as advanced as in some areas, is progressing. The degree of automation in construction is anticipated to eventually lead to humanoid robots and autonomous back loaders or cranes operating at construction sites. The prospect of a highly automated construction industry is a medium-term future prospect. Hence it is imperative to proactively understand the regulatory gaps, to support policy interventions to mitigate potential risks.

Regulation of futuristic technologies like $\mathrm{Al}$ is challenging in sectors where there is a lack of adequate tacit and applied knowledge. Al regulation is complicated by the massiveness of the construction industry, characterized by a broad spectrum of actors and activities. We propose a framework to understand the Al inclusion in the construction industry and identification of risks and regulatory gaps by considering the diverse stakeholders and their risk perception.
\end{abstract}

Keywords: Artificial Intelligence, Construction, Regulation, Risks, Risk Tolerance

\section{Author's contact information}

\section{Vishnu Sivarudran Pillai}

PhD Student

Division of Public Policy

Hong Kong University of Science and Technology

Clear Water Bay, Kowloon

Hong Kong

E:vsp@ust.hk

\section{Kira Matus}

Associate Professor, Division of Public Policy, Division of Social Science, Division of Environment \& Sustainability

Associate Head, Division of Public Policy

Director, Master of Public Policy

Hong Kong University of Science and Technology

Clearwater Bay, Kowloon

Hong Kong

E:kmatus@ust.hk 


\title{
Regulation of AI Technologies in the Construction Industry Vishnu Sivarudran Pillai and Kira Matus
}

\author{
Division of Public Policy, Hong Kong University of Science and Technology
}

\begin{abstract}
The development of Artificial Intelligence (AI) -based technologies for the construction industry, though not as advanced as in some areas, is progressing. The degree of automation in construction is anticipated to eventually lead to humanoid robots and autonomous back loaders or cranes operating at construction sites. The prospect of a highly automated construction industry is a medium-term future prospect. Hence it is imperative to proactively understand the regulatory gaps, to support policy interventions to mitigate potential risks.

Regulation of futuristic technologies like AI is challenging in sectors where there is a lack of adequate tacit and applied knowledge. AI regulation is complicated by the massiveness of the construction industry, characterized by a broad spectrum of actors and activities. We propose a framework to understand the AI inclusion in the construction industry and identification of risks and regulatory gaps by considering the diverse stakeholders and their risk perception.
\end{abstract}

Keywords: Artificial Intelligence, Construction, Regulation, Risks, Risk Tolerance

\section{Introduction}

Research on AI regulation in construction, unlike sectors such as manufacturing and information technology, is highly challenging due to the inherent complexity of the construction industry and the lack of applied knowledge in this field. In this era of "Industry 
4.0", construction companies are increasingly automating operations and digitizing processes in their race to improve productivity, safety and quality. The global construction market is forecasted to grow by $85 \%$ to $\$ 15.5$ trillion by 2030 ("Global Construction Market to Grow \$8 Trillion by 2030: Driven by China, US and India" 2018), and automation could raise productivity growth globally from $0.8 \%$ to $1.4 \%$ annually (Manyika et al. 2017). The awareness and adoption of Building Information Modelling (BIM), which reduces errors and increases productivity of operations, has grown from 10\% in 2011 to $70 \%$ in 2018 (NBS 2018). BIM + "Internet of Things" (IOT) is the formula for most of the AI applications in the construction processes. Looking to the future, autonomous construction equipment, such as the use of robotics and advanced AI could further enhance the safety and productivity of the construction sector ("Global Autonomous Construction Equipment Market Report 2018: Size, Market Share, Application Analysis, Regional Outlook, Growth Trends, Key Players, Competitive Strategies and Forecasts, 2016-2026”2019). Yet understanding of the practical and regulatory implications of this transition is sorely lacking.

The problematic characteristics of AI that differentiate AI from other automation technology are autonomy, foreseeability and causation (Scherer 2015). The characteristics of autonomy of AI reduces the need for human supervision, such as driver-less cars and Lethal Autonomous Weapon Systems (LAWS). Foresee-ability and causation are about "Outside the -box" thinking ability of AI (Scherer 2015). There is an element of surprise (or unexpectedness) in the results. Deep learning algorithms consider all the possible combinations of the features and come up with solutions that are counter-intuitive in many circumstances. This characteristic of AI is attributed to the high calculation speed, looking 
through the solution space to get a more optimised solution rather than a "satisficing" one. These features of AI, along with the inherent complexity of construction, open a new panorama of risks and regulatory challenges. It is essential to identify these regulatory gaps in order to design regulations for $\mathrm{AI}$ inclusion in construction activities.

This paper addresses the following questions:

1. What is the potential area of AI inclusion in the construction industry?

2. What are the risks associated with AI inclusion in construction?

3. What are the regulatory gaps that need to be addressed to decouple various stakeholders from the risks due to $\mathrm{AI}$ inclusion in construction?

Parveen (2018) tried to perceive the legal and regulatory challenges of AI in construction. However, this work does not consider the various stakeholders and their risk perceptions; nor does it identify the areas of potential AI inclusion in the industry. In our study, to identify the regulatory gap, we start by identifying areas with the potential for AI inclusion in the construction industry. One way to explore the $\mathrm{AI}$ inclusion in construction is to consider the tools developed by the construction startups (Bughin et al. 2017), and then to survey construction personnel. However, AI is in the nascent stage of development, and lacks the "applied knowledge" (corresponding to the actual implementation of the technology), and "tacit knowledge" (knowledge gained through experience) (Matus 2009; Polanyi \& Sen 1966). Therefore, conducting surveys among construction personnel to understand the potential AI inclusion lacks validity, as they may not be sufficiently aware of the range of future possibilities. At the same time, we deal with futuristic technologies where the product or service might have changed by the time the regulation is finally approved (Daniel Malan 
2018) and the hidden risks will only be understood once the technology is adopted in a particular field (Mandel 2009), making regulation difficult. Therefore, we understand the potential AI inclusion in construction by "deriving trends and themes" (Padalkar \& Gopinath 2016) using a systematic literature review. This approach identifies trajectory of underlying research, which in turn will underpin future technology development. The research in the fields of construction management and automation in construction acts as the "foundation of basic knowledge" (Matus 2009) for the innovation in construction regarding AI inclusion.

One feature of innovation in the construction industry is that it often occurs via "innovation spill-over" (Anadon et al. 2016; Department for Business Innovation and Skills 2014; Griliches 1991), where innovation in one technology leads to rapid improvements and new technologies in other sectors. For example, the history of BIM can be traced back to the project models that are widely used in the petrochemical, automotive and the ship-building industry (Volk et al. 2014). So after identifying the potential area of AI inclusion, we derive the risks associated with that inclusion from reports on AI inclusion in other sectors. We use Perrow's victim classification (Perrow 2011) approach to analyse the effect of risks on multiple stakeholders. Such an approach enables us to see whether the existing regulations are capable enough to decouple the various stakeholders from the possible risks due to AI inclusion.

We begin by analysing the emerging trends of automation in construction through a "systematic literature review" which consists of bibliometric analysis followed by "technology - activity mapping" where we understand and map the technology to the respective construction activities based on it's application. We propose this dual stage 
approach to improve the validity of the study as the findings of the two stages corroborate each other (triangulation), the bibliometric analysis aids the subsequent "technology activity" mapping (facilitation), both the underlying technology and it's application are explored (complimentary), which are the key approaches in mixed method research models (Bryman 2016; Zou et al. 2014). Mixed method models improve the strength of individual research paradigms of the quantitative and qualitative methods (Yin et al. 2019; Zou et al. 2014).

Since AI in construction is an evolving research area, it is imperative that we obtain a research front (Aria \& Cuccurullo 2017), define the boundary and understand the research area without any bias (Yin et al. 2019). Hence, we use the keyword co-occurrence network in the bibliometric analysis to understand the pattern or frame-work in the existing research (Aria \& Cuccurullo 2017; Yin et al. 2019) to define a research front. Keywords are the terms that represent the core of the journal article ( $\mathrm{Su} \&$ Lee 2010). Here, in the keyword co-occurrence network we consider the indexed-keywords (rather than the more specific author keywords (Zhang et al. 2016)) in the same paper (Aria \& Cuccurullo 2017; Su \& Lee 2010). Keywords share equal importance if they are mentioned in the same paper (Su \& Lee 2010).

Construction risks are related to the construction activities. For example, activities related to erection of structures has risks associated with fall from a height, fall of object etc. Therefore, in the "technology-activity mapping," we analysed journal articles to identify their domain of application, and to associate them into the construction activities, or 'activity groups,' as explained in Section 2. In Section 3, we use these activity groups to form the basis for analysing the potential risks, based on a framework that takes into account the activies and 
who will bear any impacts. We analyse the potential risks based on reports of similar AI technologies in other sectors. In Section 4, we turn to the specific case of the Indian construction industry, and analyze the adequacy of the existing regulations, and from there, are able to identify key regulatory gaps. In Section 5, we conclude by considering societal risk tolerance, and demonstration the need for future regulation

\section{Potential for AI inclusion in the construction industry}

As mentioned in the previous section, the first stage of this analysis requires a classification of the potential future activities that will be impacted by the use of $\mathrm{AI}$ in the construction industry. In order to identify the possible trajectory of AI in the construction over the medium to long term, we used Scopus to search the publications due to the better performance for accuracy and coverage compared to other search engines such as Web-of-Science, Google Scholar etc. (Osei-kyei \& Chan 2015; Yin et al. 2019). Scopus is widely used in the literature review studies in construction management to understand research trends (Hong et al. 2011; Hong \& WM Chan 2014; Ke et al. 2009; Osei-kyei \& Chan 2015; Yin et al. 2019).

There are four ways to apply AI (PWC 2017) in construction. Automated Intelligence is the automation of manual and cognitive tasks and does not involve creative ways of doing things. Automated welding systems that are known to provide excellent welding results (Eissfeller 2001) is an example for the automated intelligence . Assisted intelligence, for instance, AI surveillance system and tracking, supports construction personnel to improve performance on particular tasks. Accurate and efficient tracking, analysis and visualization of as-built (actual) status of buildings for successful project monitoring using IFC based BIM is an example currently in use (Golparvar-Fard et al. 2012). Augmented intelligence, which 
includes algorithmic decision making, enables construction personnel to do things they otherwise could not do, and make better decisions. This can include decisions on contractor selection (Awad \& Fayek 2012), and decision support tools that enables designers to enhance occupation health and safety in construction design (Cooke et al. 2008). Autonomous intelligence is decision-making process without human intervention. Autonomous systems have the ability to learn and adapt to the environment and tasks (Shen \& Simon 1994). A construction robot that can assemble pre-designed modular structures by autonomously identifying the prismatic building components like brick and blocks is as an autonomous system (Feng et al. 2015).

In order to avoid bias in determining the research frontier in this space, we start with a bibliometric analysis to capture and categorize the content of the research literature. We performed a search based on the following key words: (automat* AND construction) OR (“artificial intelligen*” AND construction) OR (robot* AND construction) OR (algorithm* AND construction) AND (autonomous AND construction). The source title was limited to (construction OR civil OR building* OR project*), with '*' used for a fuzzy search. We obtained 1609 documents for the year from 2008 to 2018. We used the "bibliometrix"(Aria \& Cuccurullo 2017) package of the R programming language to do the bibliometric analysis. Figure 1 shows an increasing trend in annual scientific production over the decade. 


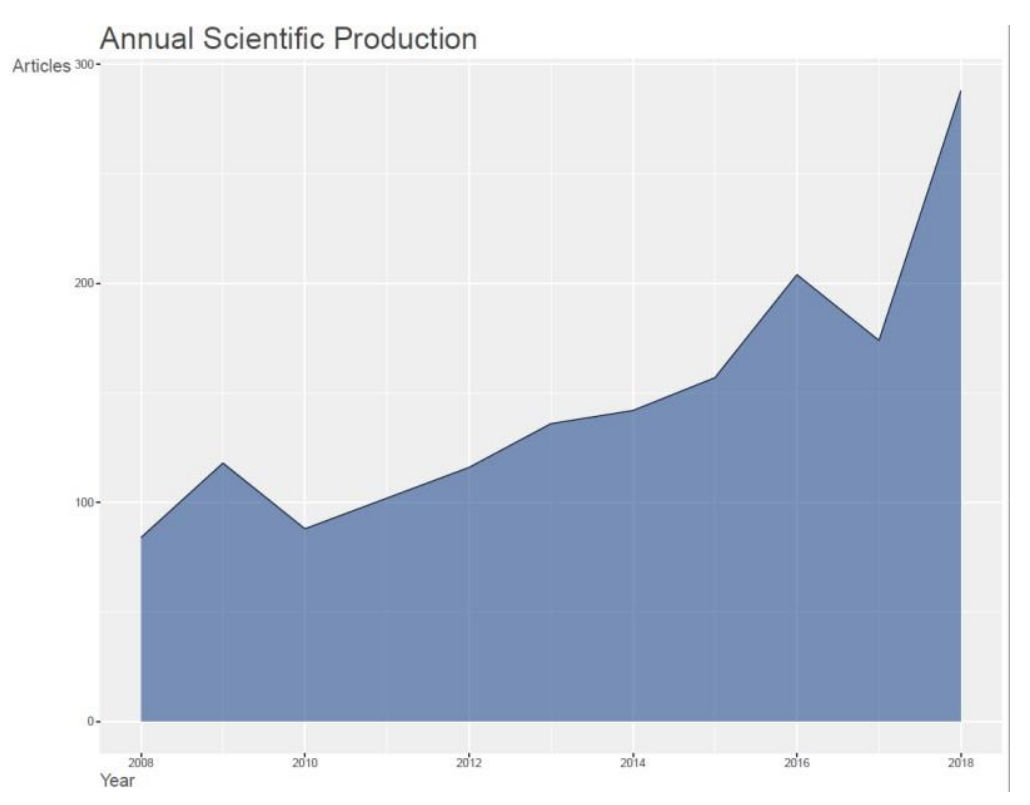

Figure 1: Annual scientific production

Figure 2 shows the keyword co-occurrences. The strength of the association (Aria \& Cuccurullo 2017) between two keywords in this Fruchterman-Reingold Layout (Fruchterman \& Reingold 1991) is represented by the diameter of the circle and the thickness of the link connecting the two keywords. The nodes with the same colour are in the same "research cluster" (Yin et al. 2019). From Figure 2, we can see a strong association between 'AI', 'decision making', 'decision support systems', 'scheduling', 'construction industry' and 'construction projects' (all part of the purple cluster). This cluster of research is primarly focusing on the use of AI for decision making in construction projects. Project monitoring and scheduling are important aspects in the study of construction management. We can see the term 'productivity' co-occuring and associated with 'construction equipment' and 'construction sites' (yellow cluster), indicating the research trend towards using AI to improve the productivity of construction equipment, as well as the processes on construction 
sites.

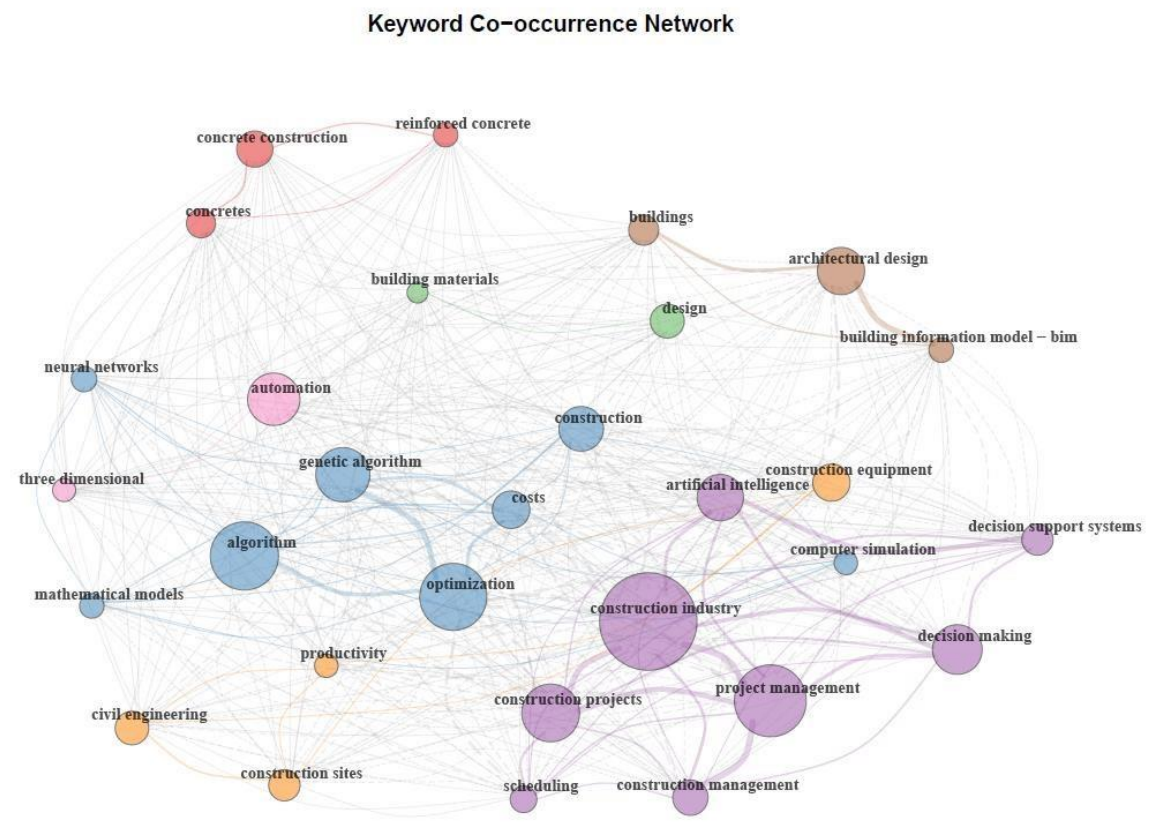

Figure 2: Keyword co-occurrence network

Next, in order to understand how artificial intelligence is being applied to construction, we do a similar search in Scopus with keywords "Artificial Intelligen*" and "construction," with source title restricted as mentioned above. We obtained 171 documents for the year 2008 to 2018. We conducted a co-word analysis (Figure 3 ) to visualize understand the research domain. This narrower focus allowed us to determine the particular techniques and applications under research - the basis of the 'activity groups' that will be discussed in detail later in this section. 


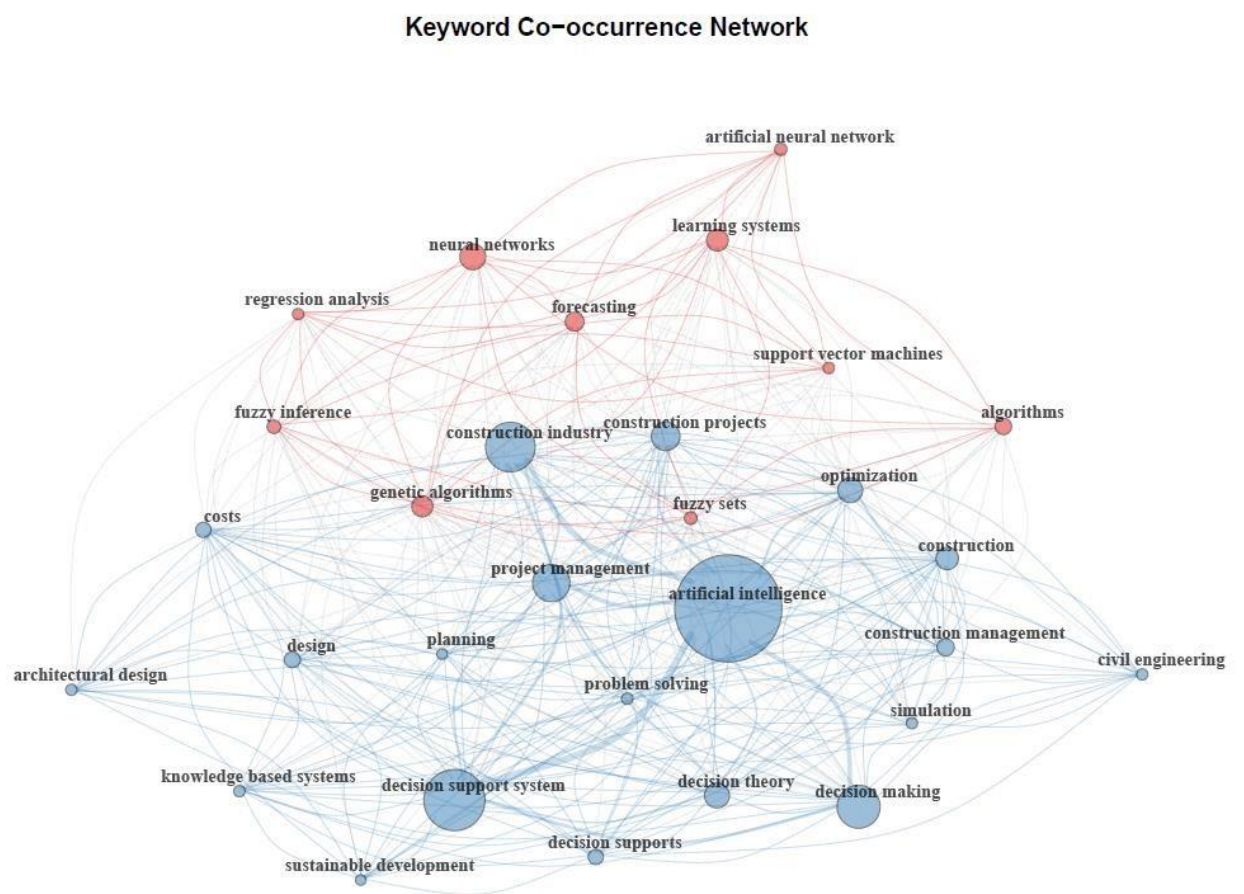

Figure 3: Keyword co-occurrence for "Artificial Intelligence" and "Construction."

In the blue cluster we can see a strong association between AI and decision systems. The research in this group is strongly associated with the application of AI in decision making, problem solving and similar project management aspects. Hence, the focus is more associated with algorithmic decision making, particularly the back-end of construction activities that do not share a direct interface with contruction sites. Construction, being highly uncertain and interdependent, is an industry in which algorithms are used to improve decision making. The blue cluster is linked to the orange cluster, which has the themes regarding specific algorithmic approaches, mainly the learning systems using different AI approaches like support vector machines and neural networks. 
To understand the research trend regarding the use of robots in construction, we used the keywords "Robot*" and "construction" with the source title restricted as above. We obtained 98 documents for the period from 2008 to 2018. In the co-word analysis, shown in Figure 4, we can see the strong association between 'automation,' 'robotics,' and 'construction industry' (blue cluster). Here we can also see the association of 'project management' and 'construction management' (orange cluster) to the more technological aspect / front end construction, where there is an interface with the construction sites. The front end construction activities are those that are done by the construction workers. We discus this in detail in the section 3 in regards to potential risks of AI.

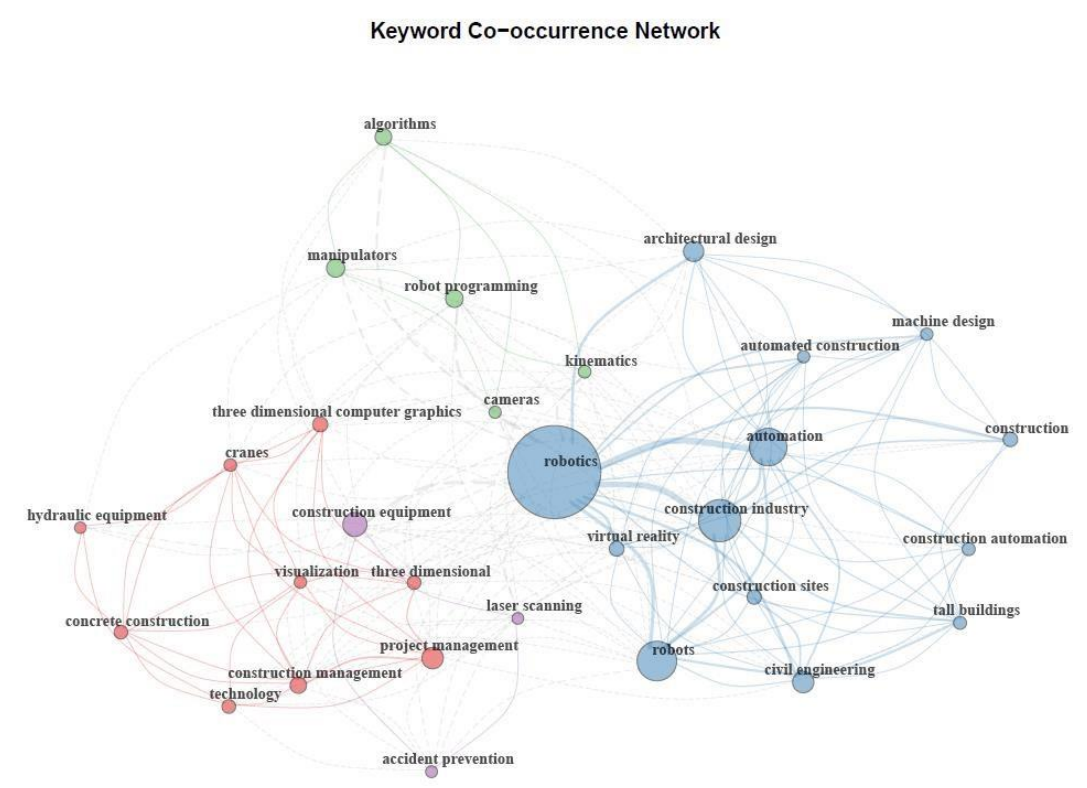

Figure 4: Keyword co-occurrence for "Robot" and "Construction"

We can see that a research trend regarding automation streamlining towards design and core construction (blue cluster). The purple cluster represents the element of safety related to 
construction equipment. Therefore, from Figure 2 and Figure 4, we can infer that research on construction robots are aiming at improving safety, even though the research on "automation" is focused on improving productivity. From Figure 3 and Figure 4 we can infer that the research on construction robots is aiming on the front-end construction activities whereas those research on the umbrella term AI, is mainly on decision making, or the the back-end construction activities.

Based on this understanding of the underlying research, we mapped the technologies into groups of construction activities. It is imperative that we understand the various construction activities in terms of particular types of AI inclusion, in order to arrive at both risks and regulatoray challenges. We classified 238 journal articles based on their applications and arrived at the following activity groups as shown in Table 1.

\section{Table 1}

Activity Groups

\begin{tabular}{|c|c|c|}
\hline $\begin{array}{l}\text { Activity } \\
\text { Groups }\end{array}$ & Papers related to & Characteristics \\
\hline $\begin{array}{c}\text { Activity } \\
\text { Group } 1 \\
\text { (Execution) }\end{array}$ & $\begin{array}{l}\text { Assembly and installation of structures, erection of } \\
\text { structures, civil engineering works like concreting, } \\
\text { bricklaying masonry, pipe laying, tunnelling } \\
\text { activities, construction robots, earthwork } \\
\text { (excavation etc.), prefabrication or fabrication } \\
\text { activities, shop assembly, finishing job including } \\
\text { painting, wall construction material handling, } \\
\text { construction method selection, survey }\end{array}$ & $\begin{array}{l}\text { High human - } \\
\text { equipment or robot } \\
\text { interaction }\end{array}$ \\
\hline
\end{tabular}




\begin{tabular}{|c|c|c|}
\hline $\begin{array}{l}\text { Activity } \\
\text { Group } 2 \\
\text { (Design) }\end{array}$ & $\begin{array}{c}\text { Design (drawings, design decisions etc.), modelling } \\
\text { construction engineering problems and } \\
\text { knowledge sharing }\end{array}$ & $\begin{array}{l}\text { Related to digital } \\
\text { design, simulation } \\
\text { and knowledge } \\
\text { sharing (privacy } \\
\quad \text { issues) }\end{array}$ \\
\hline $\begin{array}{r}\text { Activity } \\
\text { Group } 3 \\
\text { (Contract) }\end{array}$ & $\begin{array}{l}\text { Dispute resolution, bidding for projects, document } \\
\text { classification, regulation compliance, contractor } \\
\text { selection }\end{array}$ & $\begin{array}{l}\text { Offsite job } \\
\text { regulation }\end{array}$ \\
\hline $\begin{array}{r}\text { Activity } \\
\text { Group } 4 \\
\text { (Planning) }\end{array}$ & $\begin{array}{l}\text { Project planning and scheduling, resource planning, } \\
\text { progress monitoring and tracking, site } \\
\text { layout planning, construction risk management, } \\
\text { construction forecasting, method selection }\end{array}$ & $\begin{array}{l}\text { Monitoring and } \\
\text { decision-making } \\
\text { regarding resources } \\
\text { in the construction } \\
\text { site }\end{array}$ \\
\hline $\begin{array}{l}\text { Activity } \\
\text { Group } 5 \\
\text { (HSE) }\end{array}$ & $\begin{array}{l}\text { Safety, quality and sustainability (Health Safety and } \\
\text { Environment (HSE) systems) }\end{array}$ & $\begin{array}{c}\text { Ensuring safety in } \\
\text { process and quality } \\
\text { of product }\end{array}$ \\
\hline
\end{tabular}

This division is in alignment with various reports in the area of $\mathrm{AI}$ inclusion in construction (Blanco et al. 2017; Summits et al. 2018).

Figure 5 shows that most of the activities are under the activity group "Planning" which deals mainly with the algorithmic decision making. Previously, in the co-word analysis (Figure 3), we have seen that the researchers are focused on AI application towards decision making. 


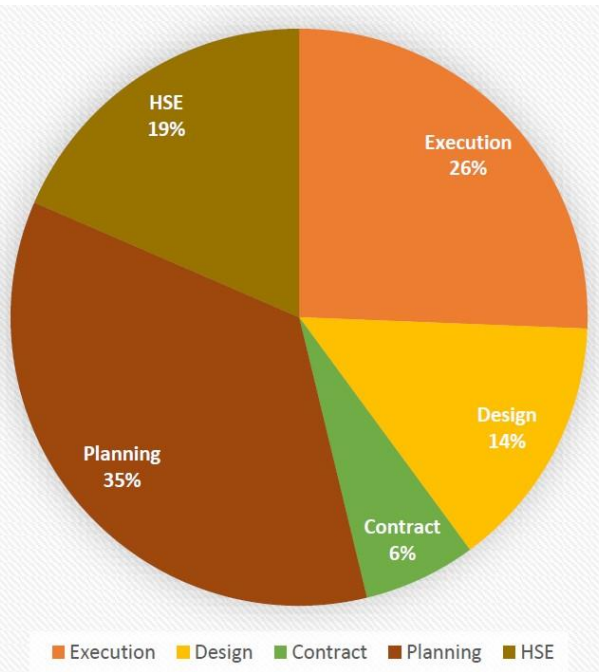

Figure 5: Distribution of articles among the activity groups

Figure 6 shows the increase in the trend of total publications over the years across various activity groups.

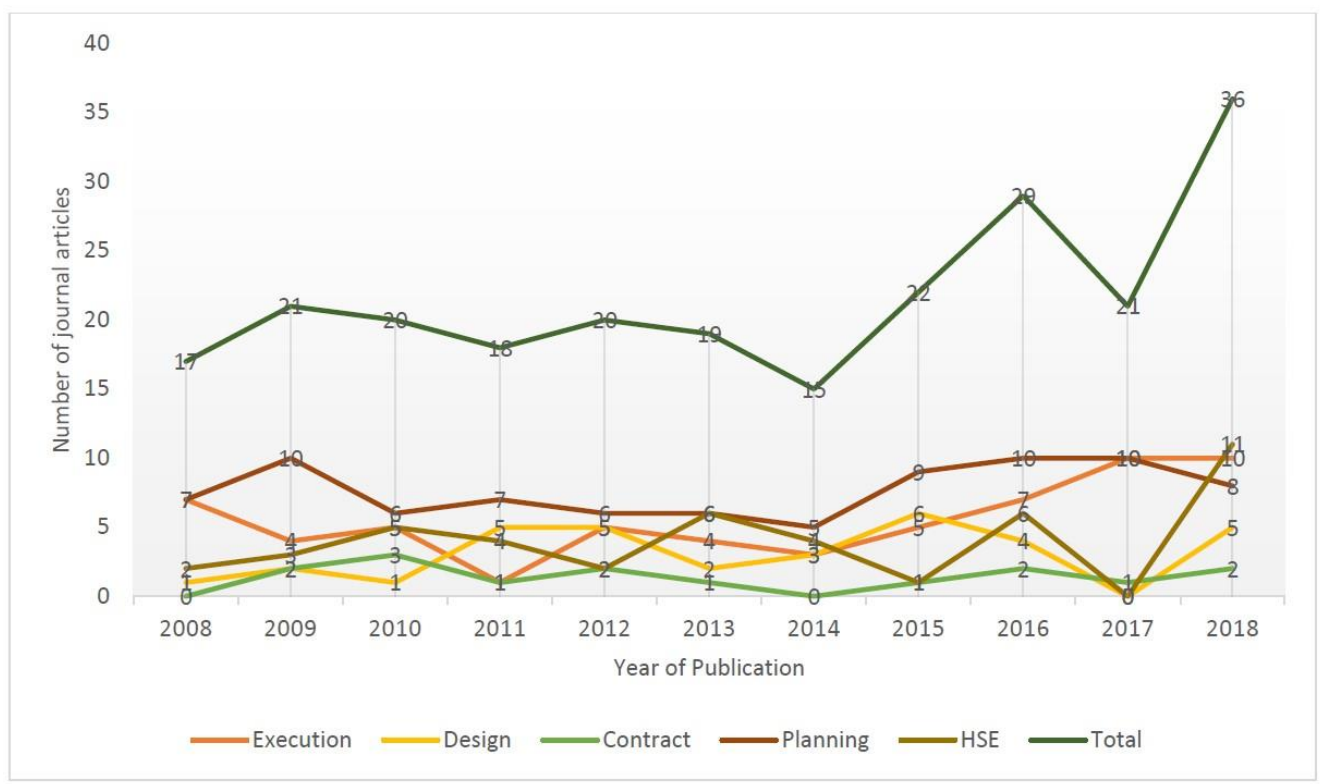


Figure 6: The trend of publications over the years

Machine Learning and deep learning algorithms became more prominent starting in 2006 (Sodhi et al. 2019), leading to an increase in interest of various researchers to apply those techniques in various fields. From 2014 onwards, the scholars tended to explore the utility of AI to ensure safety, quality and sustainability. There is an increase in trend of the Execution group since 2014 , which mainly deals with robotic construction techniques raising the issue of retrenchment. We will discuss the risks associated with AI inclusion in various activity groups in the section 3 .

The findings of the bibliometric analysis can thus be summarized as:

1. AI inclusion in construction is largely focused on improvements to productivity and safety.

2. Researchers are more interested in exploring AI for algorithimic decision making

3. The researchers who propose the use of autonomous systems in construction projects emphasise on safety along with the improvement of productivity and quality (for example automated excavation system developed by Korean Research Consortium to improve safety, quality and productivity of excavation (Seo et al. 2011)). However, we have seen that autonomous robots being developed for front-end construction activities, which raises concerns about construction accidents due to higher human - robot interaction (You et al. 2018). 


\section{Potential Risks in AI}

Along with the risks of technological unemployment, AI shares the potential risks of other emerging technologies that are related to automation such as industrial accidents, quality concerns of the product etc. We have identified the potential risks of AI inclusion by

1. Identifying the potential types of victims - which can include workers, the surrounding community, and others.

2. Identifying the specific tasks (within the activity groups), the possibility of AI inclusion on these tasks, and the risks associated with the AI inclusion in these tasks.

The risks identified from reports regarding AI development in various sectors (Solon et al., 2017; Whittaker, 2018) are:

a) Job displacement causing unemployment, retrenchment and lay-off

b) Error and bias in $\mathrm{AI}$ assisted hiring process

c) Ethical issues and risks in worker surveillance using AI systems

d) Risks from AI-assisted decision making in construction sites

e) Risks related to real-time tracking to ensure safety and quality

f) Accidents due to autonomous systems

In the subsequent subsections, we have mapped the way these risks manifest in the construction sector in the various activity groups.

In order to identify who will bear the impacts of $\mathrm{AI}$ in the construction industry, we have classified the construction personnel into seven impact groups. The members of the impact groups are humans who are part of the system and are characterized by their specialization, 
mobility and awareness regarding technological advancement. This is similar to the victim classification by Perrow (2011). A comparison between Perrow's classification and our classification is as shown in Table 3. While Perrow (2011) considered victims of catastrophic accidents, we consider impact groups (as in Table 2) based on the socio-political as well as physical risks from new technology (technology change).

Table 2

The Impact Groups

\begin{tabular}{|c|c|c|c|c|}
\hline $\begin{array}{c}\text { Impact Group } \\
\text { (IG) }\end{array}$ & Characteristics & Mobility & Example & AG \\
\hline $\begin{array}{c}\text { IG } 1 \\
\text { (Specialists) }\end{array}$ & $\begin{array}{c}\text { High degree of } \\
\text { specialization. Less } \\
\text { aware of the } \\
\text { technological } \\
\text { advancement }\end{array}$ & $\begin{array}{l}\text { Can move from one } \\
\text { organization to other but } \\
\text { within the trade (civil, } \\
\text { mechanical etc.) }\end{array}$ & $\begin{array}{l}\text { Welder, } \\
\text { Khalasi, } \\
\text { Helper, } \\
\text { Fitter, } \\
\text { Draftsman } \\
\text { and } \\
\text { Fabricator }\end{array}$ & $\begin{array}{c}1 \text { and } \\
5\end{array}$ \\
\hline $\begin{array}{c}\text { IG } 2 \\
\text { (Supervisors) }\end{array}$ & $\begin{array}{c}\text { More supervisory job. } \\
\text { Less aware of the } \\
\text { technological } \\
\text { advancement }\end{array}$ & $\begin{array}{c}\text { Can move from one } \\
\text { organization to other but } \\
\text { within the trade. Can move } \\
\text { to IG3 in due course of } \\
\text { experience (Vertical } \\
\text { Mobility) }\end{array}$ & $\begin{array}{c}\text { Supervisors, } \\
\text { Design } \\
\text { engineers } \\
\text { and Site } \\
\text { Engineers }\end{array}$ & $\begin{array}{l}1,2,3,4 \\
\text { and } 5\end{array}$ \\
\hline
\end{tabular}




\begin{tabular}{|c|c|c|c|c|}
\hline $\begin{array}{l}\text { IG } 3 \text { (Middle } \\
\text { Managers) }\end{array}$ & $\begin{array}{c}\text { Resource Management } \\
\text { and planning. Aware } \\
\text { of the technology } \\
\text { advancement }\end{array}$ & $\begin{array}{c}\text { Can move from one } \\
\text { organization to other and } \\
\text { from one trade to other } \\
\text { (Less Horizontal mobility). } \\
\text { Can move to IG4 in due } \\
\text { course of experience } \\
\text { (Vertical Mobility) }\end{array}$ & $\begin{array}{l}\text { Middle } \\
\text { managers - } \\
\text { Asst. } \\
\text { managers } \\
\text { and } \\
\text { Construction } \\
\text { managers }\end{array}$ & $\begin{array}{c}2,3 \\
\text { and } 4\end{array}$ \\
\hline \multirow[t]{2}{*}{$\begin{array}{l}\text { IG } 4 \text { (Project } \\
\text { Decision } \\
\text { Makers) }\end{array}$} & $\begin{array}{l}\text { Decision Makers - } \\
\text { Project Level } \\
\text { Resources. Highly } \\
\text { aware of the }\end{array}$ & $\begin{array}{l}\text { Can move from one sector } \\
\text { to other. Can move to IG5 } \\
\text { in due course of experience }\end{array}$ & $\begin{array}{c}\text { Project } \\
\text { managers, } \\
\text { Regional } \\
\text { managers }\end{array}$ & $\begin{array}{c}3 \text { and } \\
4\end{array}$ \\
\hline & $\begin{array}{l}\text { technological } \\
\text { advancement }\end{array}$ & $\begin{array}{c}\text { (Both Vertical and } \\
\text { Horizontal Mobility) }\end{array}$ & & \\
\hline $\begin{array}{c}\text { IG 5 } \\
\text { (Organizational } \\
\text { Decision } \\
\text { Makers) }\end{array}$ & $\begin{array}{l}\text { Decision Makers. } \\
\text { Make the decision } \\
\text { regarding technology } \\
\text { adoption }\end{array}$ & High mobility & $\begin{array}{l}\text { Region head, } \\
\text { company } \\
\text { head }\end{array}$ & $\begin{array}{c}3 \text { and } \\
4\end{array}$ \\
\hline IG 6 (Client) & $\begin{array}{l}\text { Concerned about the } \\
\text { quality of the product } \\
\text { and speed of the } \\
\text { process }\end{array}$ & NA & $\begin{array}{l}\text { The end } \\
\text { users, client }\end{array}$ & \\
\hline $\begin{array}{c}\text { IG } 7 \\
\text { (Community) }\end{array}$ & $\begin{array}{l}\text { Doesn't participate in } \\
\text { the process. Tend to be } \\
\text { unaware of the } \\
\text { process or technology } \\
\text { advancement }\end{array}$ & NA & $\begin{array}{l}\text { The people } \\
\text { residing } \\
\text { close to the } \\
\text { construction } \\
\text { sites }\end{array}$ & 5 \\
\hline
\end{tabular}

Table 3 
Comparison of victims

\begin{tabular}{|c|c|c|}
\hline Victim Groups & $\begin{array}{c}\text { Perrow's } \\
\text { classification }\end{array}$ & $\begin{array}{c}\text { Classification by the authors } \\
\text { (Impact Groups) }\end{array}$ \\
\hline $\begin{array}{c}\text { The construction personnel } \\
\text { those are participants and } \\
\text { bear the risks }\end{array}$ & Victim 1 & $\begin{array}{c}\text { Specialists, Supervisors, Middle } \\
\text { Managers, Project Decision Makers, } \\
\text { Organizational Decision Makers }\end{array}$ \\
\hline The client & Victim 2 & Client \\
\hline $\begin{array}{c}\text { The person who are not } \\
\text { aware of the operation or not } \\
\text { part of the system }\end{array}$ & Victim 3 & Community \\
\hline $\begin{array}{c}\text { The future generation as } \\
\text { suggested by Perrow }\end{array}$ & Victim 4 & $\begin{array}{c}\text { Community (loss of employment } \\
\text { opportunity to the new generation) }\end{array}$ \\
\hline
\end{tabular}

3.1. Job displacement causing unemployment, retrenchment and lay-off

It is difficult to predict job loss that can be attributed to AI. However, the employment implications can be deduced based on particular activities being targeted. The vulnerability of the construction personnel to the risk of job displacement depends upon the nature of their job. We can infer from Figure 7 that earthwork, assembly of structures, fabrication, lifting operations, concrete and masonry has the largest share of publications. AI inclusion improves the productivity of these jobs. Semi-Automated-Mason (SAM) is proved to be capable of laying three times more bricks than a human construction worker (Sklar 2015). 


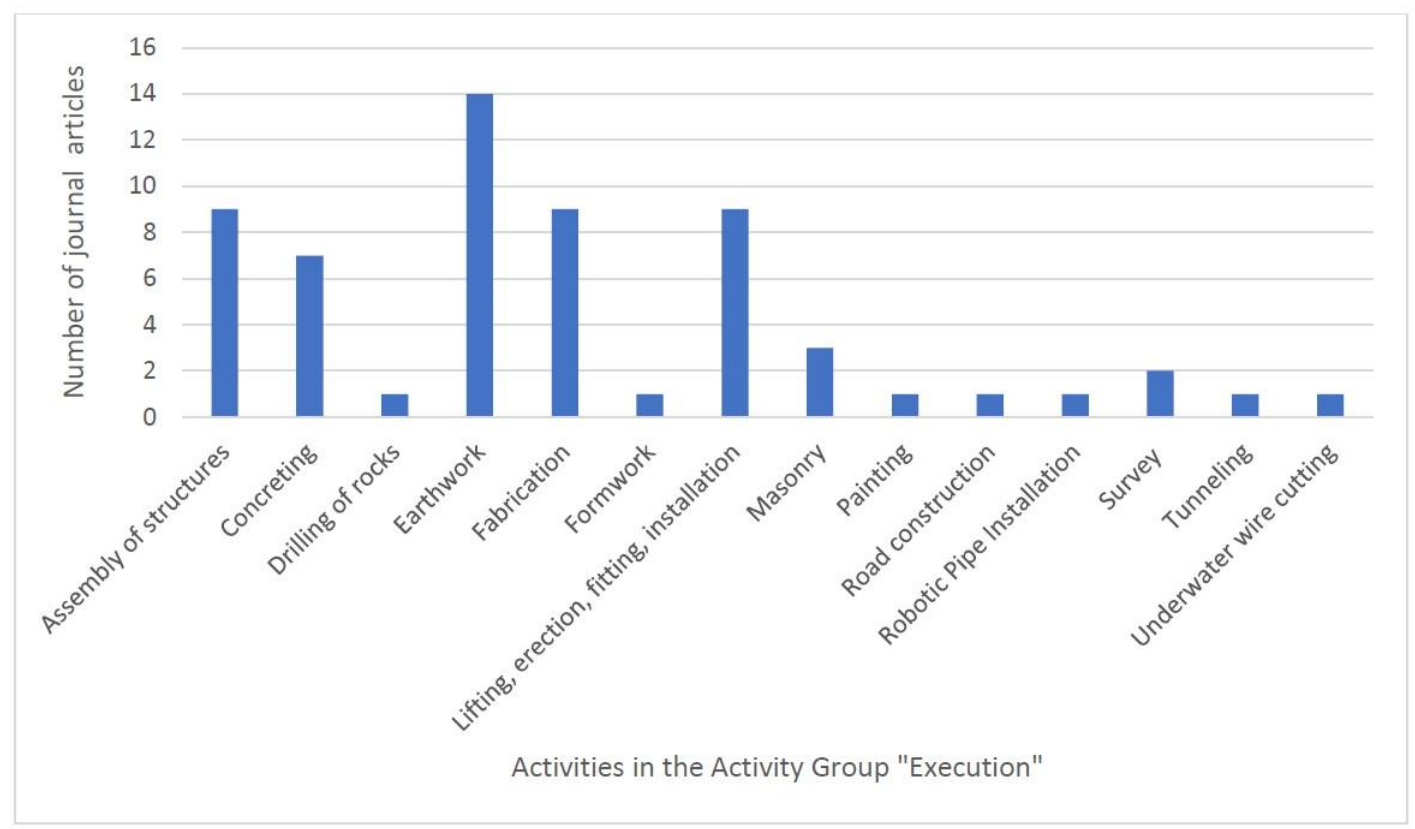

Figure 7: The distribution of articles in the activity group "execution"

Given this background, we can then infer the impacts on different groups. The frontline construction workers (specialists) are the workmen employed as contract labour. The specialists can move from one organization to another, but it is challenging for them to shift to other sectors (less horizontal mobility) or from specialists to supervisors and above (less vertical mobility). However, supervisors and engineers in due course of time and experience can become middle managers or decision makers. Their job is mainly man-management, resource allocation among the workers, study the drawings and regular supervision of the job. It is difficult for them to move between the sectors, due to their lack of knowledge regarding them. Middle managers have a background in construction management. Construction management is a variant of project management. Hence, they have the horizontal mobility as they can shift to other sectors of project management. They are aware of the emerging technologies and can move horizontally between the sectors if they plan their learning curve. 
The project managers are the decision makers of the project site. Project managers are needed in almost every sector. The organisational decision makers are highly mobile as they are the decision makers of the organisations. Irrespective of the sectors, they take decisions on where to invest, how much to invest, and decisions on acquisitions. The client are the users of the product. They are concerned about the quality of the product, the safety of the process, and the speed of production. The community refers to the environment in general and are affected by job displacement, pollution and accidents. Table 4 shows the effect of various technologies on the impact groups in terms of their job displacement.

Table 4

Effect of job displacement on victim groups

\begin{tabular}{|c|c|c|c|}
\hline Potential AI Technology & Job replaced & $\begin{array}{l}\text { Activity } \\
\text { Group }\end{array}$ & $\begin{array}{l}\text { Impact } \\
\text { Group } \\
\text { effected }\end{array}$ \\
\hline $\begin{array}{l}\text { Autonomous Robotic Construction } \\
\text { Techniques - Autonomous Intelligence }\end{array}$ & $\begin{array}{l}\text { The frontline } \\
\text { construction } \\
\text { workers }\end{array}$ & Execution & $\begin{array}{l}\text { Specialists } \\
\text { and } \\
\text { Supervisors }\end{array}$ \\
\hline $\begin{array}{c}\text { Automated Planning and Scheduling - } \\
\text { Automated Intelligence }\end{array}$ & $\begin{array}{l}\text { Construction } \\
\text { Planners }\end{array}$ & Planning & $\begin{array}{l}\text { Supervisors } \\
\text { and Middle } \\
\text { Managers }\end{array}$ \\
\hline $\begin{array}{c}\text { Automated Design - Automated } \\
\text { Intlligence }\end{array}$ & $\begin{array}{l}\text { Design, } \\
\text { Drawing }\end{array}$ & Contract & $\begin{array}{l}\text { Specialists, } \\
\text { Supervisors } \\
\text { and Middle } \\
\text { Managers }\end{array}$ \\
\hline
\end{tabular}




\begin{tabular}{|c|c|c|c|}
\hline $\begin{array}{c}\text { Automated information retrieval, } \\
\text { monitoring and control - Automated } \\
\text { Intelligence }\end{array}$ & $\begin{array}{c}\text { Data entry } \\
\text { officers, billing } \\
\text { engineers }\end{array}$ & Planning & $\begin{array}{c}\text { Specialists, } \\
\text { Supervisors } \\
\text { and Middle } \\
\text { Managers }\end{array}$ \\
\hline $\begin{array}{c}\text { Automated Decision Making in } \\
\text { construction sites (including desing } \\
\text { decisions, material and equipment } \\
\text { selection, resource allocation) - } \\
\text { Augmented Intelligence }\end{array}$ & $\begin{array}{c}\text { Decision makers } \\
\text { in construction } \\
\text { sites }\end{array}$ & Planning & Middle \\
Managers \\
and Project \\
Decision \\
Makers \\
\hline
\end{tabular}

\subsection{Error and bias in $\mathrm{AI}$ assisted hiring process}

There are AI driven human resource programs that can scan through a variety of sources to point out the right talent or the job candidates by considering the job descriptions given by the employer (Wall et al. 2017). These systems are sources of gender and community bias, leading to discrimination. Navarro-Astor et al. (2017) state that woman in the construction sector in developing countries like India and Bangladesh are at the bottom end of the job hierarchy as unskilled helpers. The AI assisted hiring process will remain biased because of this "occupational segregation" in the available data. Also, construction, like any other traditional labor-intensive sector, has community specific preferences to certain job categories. The cultural inheritance of skills makes these communities known for this job. The training data, has this bias and will invariably affect the hiring decisions (similar to AI assisted predictive policing (Solon et al. 2017)). With the advent of technical schools and 
institutions and with the increased automation in this sector, these skill inheritances or gender-based occupational segregation have no significance in the job market. Moreover, recruiting workers from a community or a gender for a low or high paying job will exacerbate the income inequality among the communities.

3.3. Ethical issues and risks in worker surveillance using AI systems (AI - "the new boss")

We have seen in Section 2 the number of articles on tracking and monitoring of resources. Employing neural networks to classify the workers' movements along with sensors (e.g., sensors attached to the smartphone) (Akhavian \& Behzadan 2016) enables automated recognition of worker's data. The data is used for worker's training and to allocate workers based on their productivity.

However, employers are using AI to amplify surveillance to increase the potential for centralised control and oppression (Whittaker 2018). It is not unusual that construction companies provide smartphones to their employees. Managers are provided with laptops. A typical smartphone is equipped with a gyroscope, an accelerometer to promptly understand device orientation, coupled with GPS, camera, and touch screen (Kim et al. 2013). The data extracted can be used for identifying the behaviour patterns of the workers, thereby replacing incentive based man-management with suppression. Workers may not be aware of the monitoring process, as in the Uber case (Solon et al. 2017). Furthermore, use of these monitoring systems to incentivize productivity or reduce overtime may lead to worker dissatisfaction, higher rates of turnover, and even impacts on quality. 


\subsection{Risks with AI-assisted decision making in construction sites}

We have seen the strong association between AI and decision making in the co-word analysis. The presence of diverse stakeholders in an uncertain environment makes decision making in construction difficult. The "collaborative decision-making framework" (Anumba et al. 2002) that ensures the participation of the critical stakeholders in construction activity is the key to the development of technology like Building Information Modeling (BIM). From the coword analysis earlier, we saw the association between BIM and decision support systems (Chen et al. 2015). BIM, along with various digital data sources and scanning techniques, is evolving as a method for automatic modelling and design of structures (Laefer \& TruongHong 2017). The key concern with such a system in the era of cybersecurity is the "Digital Risk" (Boyes \& Luck 2015). BIM enables the collaboration of the various stakeholders by sharing the information of the building components throughout a building's life cycle (Motawa \& Almarshad 2013). Sharing of information is always a risk as the external parties knows about the layout of the building and may not maintain the confidentiality leading to disclosure of intellectual property, personally identifiable information, essential security features of the buildings etc.

"Any decision has its origin in a dissatisfaction, i.e., the difference between the current state of affairs and the most desired one" (Pomerol 1997). Therefore, the decisions taken on the construction site greatly depends on the project progress. The ongoing project work is compared with a baseline schedule (the most desired state) and the delays or cost-overruns are predicted. "ALICE" developed by the scientists in Stanford University uses 3D BIM and rule-based systems to generate millions of baseline schedule sequences (BIM+2018). These 
rules are rooted in historical data. Lack of reliable historical data leads to errors in productivity estimation (Golabchi et al. 2016) leading to an error in the baseline scheduling process (activity duration, resource planning etc.). Therefore, the baseline schedules generated are more prone to uncertainties as compared to the manual duration estimation and scheduling where the construction personnel consider buffers (as described by (Perrow 2011)) to account for the complexity of the construction process.

The other important issue with the data-driven systems that seek patterns and correlations is the very nature of construction projects: "every project is unique". Hence data-driven approaches must go through a layer of filtering from experts before making final decisions related to operations or legal matters of a particular project site (Hanna et al. 2018).

Ultimately these lead to the liability puzzle - if the system suggests a decision and the project is delayed - who should be accountable?

\subsection{Risks related to real-time tracking and ensuring safety and quality}

Real-time tracking of equipment and workers to ensure construction safety (Wu et al. 2010) is analogous to all those safety devices in the complex systems (nuclear plant, petrochemical plant etc.), and over reliance on these safety systems may mislead the system operators to overlook possible system accidents. Many activities will remain unrecognisable due to the lack of sufficient training data. For example, the activity of 'transporting' is like that of 'walking', as a computer exhibits difficulties in differentiating between tasks when small objects are involved (Luo et al. 2018). Many of these data have insufficient techniques to adopt neural networks; as part of deep learning algorithms, they lack foreseeability. Over 
reliance on tracking techniques to ensure safety and quality, if they cause workers to ignore other (non-AI) safety standard procedures on site, and may lead to accidents or system failures and cause liability issues.

\subsection{Accidents due to autonomous systems}

Autonomous intelligence is the decision-making process without human intervention (PWC 2017). The advantage of autonomous systems is their ability to learn and adapt to the environment and tasks (Shen \& Simon 1994). Herbert A Simon says: " if the intelligent system knows the actual situation only in part, hence must be concerned with incompleteness and inaccuracies of its picture of reality; for its plans will frequently fail to reach the intended goals or have undesired side effects and it must have means for recognizing these failures, remedying them as far as possible, and re-establishing its contact with the external reality" (Shen \& Simon 1994). This is relevant in the context of accidents with autonomous vehicles.

The reliability of the autonomous vehicle is always a concern for policymakers (Goodall 2014), due to "undesired side-effects". The ethical decision making of automated vehicles, to understand and apply ethics on a new situation is another source of potential risk associated with the autonomous system (Goodall 2014). These risks related to the autonomous systems are critical when they are engaged in construction sites as they may cause construction accidents.

Autonomous systems in the construction sites, (i.e. loaders, excavators, and cranes) use GPS, Inertial Measurement Units (IMU), and vision systems (LIDAR), along with machine learning algorithms, to accurately position and detect the objects in the surroundings. Being 
a labour-intensive sector, the autonomous system must work with and alongside humans on a construction site. The prediction module of the system equipped with deep learning algorithms may not be capable enough to anticipate human behaviour. The existing methods to measure the accuracy of prediction modules may not ensure a fool-proof system, as deep learning algorithms are considered "black-box models" owing to their un-foreseeability.

The other issue with autonomous systems is that unlike other construction equipment, they cannot be shifted between project sites. Autonomous equipment learns from the surroundings and responds. The autonomous equipment that was deployed in one construction site have learnt may fail in a completely different project site. This is because of the unique nature of the construction projects..

Therefore, safety will be improved by reducing the human-robot interaction, and by reducing the the interaction between two autonomous systems. But this reduces the flexibility of the construction site to deal with the unforeseen circumstances that arise in construction activities. Construction sites does not follow the input-process-output sequence. But the inclusion of autonomous systems demands a certain level of standardization in construction sites, along with the training the construction personnel who work along the autonomous systems.

Finally, there is the uncertainty about the application of liability law. Who is responsible for the safety of the autonomous systems (as mentioned above with autonomous car) and the quality of the work by construction robots? Does liability rest with the manufacturer of the equipment or the developer of the autonomous system (Schellekens 2015) or the employer (owner or contractor) who owns the construction site? 


\section{Regulatory gaps in Indian Construction Industry}

The largest share for the global construction industry will continue to occur in Asia Pacific due to the large markets of South East Asia, China, Japan and India (Global Construction Outlook to 2022 2018). The Global Construction Report 2030 states that "the construction market in India will grow almost twice as fast as China to 2030, providing a new engine of global growth in emerging markets"("Global Construction Market to Grow \$8 Trillion by 2030: Driven by China, US and India” 2018). In this section, we apply the findings from sections 2 and 3 to the Indian construction sector, as this is a context in which, given both current low productivity and predicted high growth, we expect to see a strong demand for the use of AI technologies. We analyzed the prevailing regulations in the Indian construction industry and identified those that would apply to particular activities and/or impact groups. From this we were able to identify a set of regulatory gaps, which can be sorted into gaps related to the six risks of AI inclusion (Section 2). The term "regulatory gap" in this article refers to the inadequacy in regulations as a result of the new risks that evolve in the construction sector due to potential AI inclusion. The result of our analysis is as shown in Table 5 below.

[ Table 5: Risks and issues with the existing regulations] 
Table 5:

Risks and issues with the existing policies

\begin{tabular}{|c|c|c|c|c|c|c|c|}
\hline Sl.No. & $\begin{array}{c}\text { Impact } \\
\text { Characterist } \\
\text { ics }\end{array}$ & $\begin{array}{c}\text { Impact } \\
\text { Notation }\end{array}$ & Impact Group & $\begin{array}{c}\text { Existing } \\
\text { policies and } \\
\text { regulations }\end{array}$ & $\begin{array}{c}\text { Characteristics } \\
\text { of the existing } \\
\text { policy or act }\end{array}$ & $\begin{array}{l}\text { Effect on the } \\
\text { impact }\end{array}$ & $\begin{array}{l}\text { Issues with the } \\
\text { existing policies }\end{array}$ \\
\hline \multicolumn{8}{|c|}{ Job Displacement } \\
\hline 1 & $\begin{array}{l}\text { Increase in } \\
\text { unemployme } \\
\text { nt due to lack } \\
\text { of demand } \\
\text { for labour } \\
\text { due to AI } \\
\text { systems in } \\
\text { the } \\
\text { construction } \\
\text { industry }\end{array}$ & RI-1 & $\begin{array}{l}\text { Specialists, } \\
\text { Supervisors } \\
\text { and } \\
\text { Community }\end{array}$ & $\begin{array}{c}\text { Mahatma } \\
\text { Gandhi } \\
\text { National } \\
\text { Rural } \\
\text { Employment } \\
\text { Guarantee } \\
\text { Act } \\
\text { (MNREGA) } \\
\text { - 2005 } \\
\text { (Mahatma } \\
\text { Gandhi } \\
\text { National } \\
\text { Rural } \\
\text { Employment } \\
\text { Guarantee } \\
\text { Act }\end{array}$ & $\begin{array}{l}\text { Provide the adult } \\
\text { members of every } \\
\text { household at least } \\
100 \text { days of } \\
\text { guaranteed } \\
\text { wage employment } \\
\text { of unskilled } \\
\text { manual work in a } \\
\text { financial year. }\end{array}$ & $\begin{array}{c}\text { Provide horizontal } \\
\text { mobility }\end{array}$ & $\begin{array}{l}\text { No provision for } \\
\text { skilled labor }\end{array}$ \\
\hline
\end{tabular}




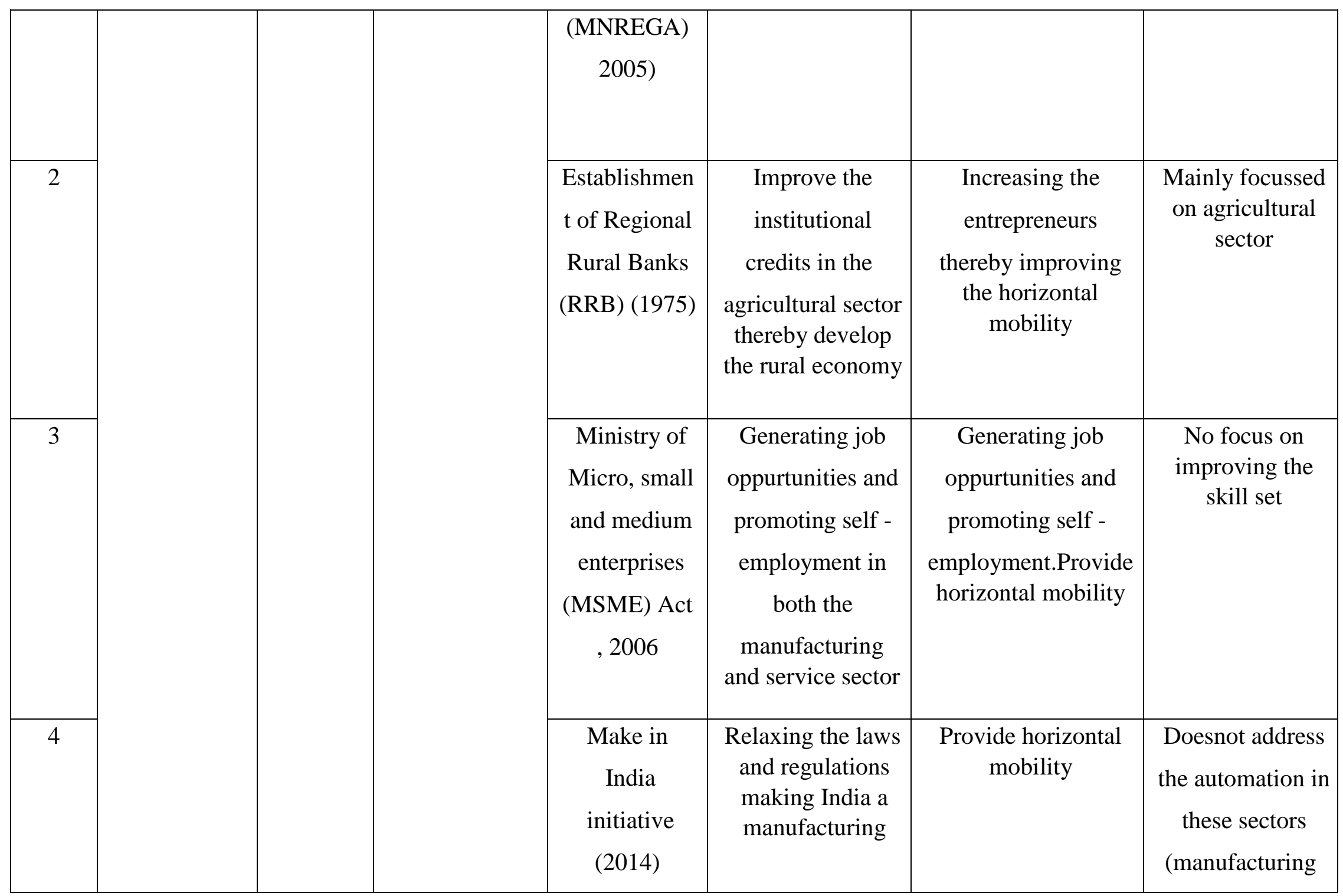




\begin{tabular}{|c|c|c|c|c|c|c|c|}
\hline & & & & & $\begin{array}{l}\text { hub increasing } \\
\text { mobility }\end{array}$ & & $\begin{array}{l}\text { sector is highly } \\
\text { automated) }\end{array}$ \\
\hline 5 & & & & $\begin{array}{c}\text { National Skill } \\
\text { Development } \\
\text { Mission ( } \\
\text { 2015) }\end{array}$ & $\begin{array}{l}\text { Vocational } \\
\text { training in } \\
\text { schools }\end{array}$ & $\begin{array}{l}\text { To bridge the skill } \\
\text { deficit needed for the } \\
\text { job - thereby } \\
\text { promoting horizontal } \\
\text { mobility }\end{array}$ & $\begin{array}{l}\text { Have a massive } \\
\text { backlog of skill } \\
\text { deficit and the } \\
\text { lack of fund to } \\
\text { address them }\end{array}$ \\
\hline 6 & $\begin{array}{l}\text { Reduction of } \\
\text { income on } \\
\text { the jobs that } \\
\text { have high } \\
\text { potential for } \\
\text { automation }\end{array}$ & RI-2 & $\begin{array}{c}\text { Specialists, } \\
\text { Supervisors,Mi } \\
\text { ddle Managers } \\
\text { and } \\
\text { Community }\end{array}$ & $\begin{array}{c}\text { Minimum } \\
\text { Wages Act } \\
1948-\mathrm{u} / \mathrm{s} \\
\text { 12,20,21,22A } \\
\text { (u/s means } \\
\text { "under } \\
\text { section") }\end{array}$ & $\begin{array}{c}\text { Payment of wages } \\
\text { less than the } \\
\text { Minimum Wage } \\
\text { Rate (MRW) is an } \\
\text { offence (u/s } \\
12,20,22 \mathrm{~A}) \text { - } \\
\text { investigation of } \\
\text { claims by the } \\
\text { employee } \\
\text { regarding the rate } \\
\text { of wages (u/s } \\
20,21)\end{array}$ & $\begin{array}{l}\text { To prevent the } \\
\text { reduction of wages } \\
\text { due to automation }\end{array}$ & $\begin{array}{l}\text { Very less MRW } \\
\text { for } \\
\text { SUPERVISORS } \\
\text { and MIDDLE } \\
\text { MANAGERS in } \\
\text { most of the } \\
\text { States. Offence } \\
\text { and penalty } \\
\text { sections are } \\
\text { weak. }\end{array}$ \\
\hline
\end{tabular}




\begin{tabular}{|c|c|c|c|c|c|c|c|}
\hline 7 & $\begin{array}{l}\text { Retrenchmen } \\
\mathrm{t} \text { and layoff } \\
\text { of employees }\end{array}$ & RI-3 & $\begin{array}{c}\text { Specialists,Sup } \\
\text { ervisors,Middl } \\
\text { e Managers } \\
\text { and } \\
\text { Community }\end{array}$ & $\begin{array}{c}\text { Industrial } \\
\text { Disputes Act } \\
1947 \mathrm{u} / \mathrm{s} 25 \mathrm{C}, \\
25 \mathrm{M}, 25 \mathrm{FF} \\
\text { and } 25 \mathrm{~N}\end{array}$ & $\begin{array}{l}\text { Compensation for } \\
\text { retrenchment (u/s } \\
25 \mathrm{f}, 25 \mathrm{n}) \text { and } \\
\text { layoff }(\mathrm{u} / \mathrm{s} \\
25 \mathrm{c}, 25 \mathrm{~m}) \text { of } \\
\text { construction } \\
\text { workers.(Section } \\
250 \text { in case of } \\
\text { closure) }\end{array}$ & $\begin{array}{l}\text { Prevent the illegal } \\
\text { lay-off and } \\
\text { retrenchment due to } \\
\text { automation without } \\
\text { any compensation }\end{array}$ & $\begin{array}{c}\text { Only for } \\
\text { employee in the } \\
\text { workmen } \\
\text { category. } \\
\text { Doesnot include } \\
\text { the managerial } \\
\text { functions or } \\
\text { those with wages } \\
\text { greater than INR } \\
\text { 10000. Only } \\
\text { applicable to } \\
\text { SPECIALISTS. } \\
\text { Retrenchment is } \\
\text { allowed with } \\
\text { compensation }\end{array}$ \\
\hline \multicolumn{8}{|c|}{ Error and bias in AI assisted hiring process } \\
\hline 8 & $\begin{array}{l}\text { Gender based } \\
\text { occupational } \\
\text { segregation } \\
\text { causing } \\
\text { income }\end{array}$ & RI-4 & All & $\begin{array}{c}\text { IT Act } 2008- \\
\text { u/s } 72 \mathrm{~A}\end{array}$ & $\begin{array}{l}\text { Prevent the } \\
\text { employee from } \\
\text { sharing the data } \\
\text { without the }\end{array}$ & $\begin{array}{l}\text { Prevent the transfer } \\
\text { of personal } \\
\text { information data of } \\
\text { the existing } \\
\text { employee without }\end{array}$ & $\begin{array}{l}\text { Doesnot prevents } \\
\text { the usage of data } \\
\text { by the } \\
\text { employer's own }\end{array}$ \\
\hline
\end{tabular}




\begin{tabular}{|c|c|c|c|c|c|c|c|}
\hline & $\begin{array}{l}\text { inequality } \\
\text { among the } \\
\text { gender }\end{array}$ & & & & $\begin{array}{c}\text { consent of the } \\
\text { employee }\end{array}$ & $\begin{array}{l}\text { the consent of the } \\
\text { employee to a third } \\
\text { party (hiring agency) }\end{array}$ & $\begin{array}{l}\text { HRD (they are } \\
\text { not third party) }\end{array}$ \\
\hline 9 & $\begin{array}{c}\text { Community } \\
\text { based } \\
\text { occupational } \\
\text { segregation } \\
\text { causing } \\
\text { income } \\
\text { inequality } \\
\text { among } \\
\text { various } \\
\text { communities }\end{array}$ & RI-5 & All & & & & \\
\hline 10 & $\begin{array}{l}\text { Hiring people } \\
\text { with wrong } \\
\text { skill set, } \\
\text { leading to } \\
\text { construction } \\
\text { project } \\
\text { failure, } \\
\text { quality issues }\end{array}$ & RI-6 & $\begin{array}{c}\text { Middle } \\
\text { Managers,Proj } \\
\text { ect Decision } \\
\text { Makers, } \\
\text { Organizational } \\
\text { Decision } \\
\text { Makers and } \\
\text { Community }\end{array}$ & $\begin{array}{c}\text { Indian } \\
\text { Contracts Act } \\
1872\end{array}$ & $\begin{array}{l}\text { Entitles the party } \\
\text { to follow the } \\
\text { contracts (the } \\
\text { sepcial conditions } \\
\text { of liability } \\
\text { mentioned in the } \\
\text { contract) }\end{array}$ & $\begin{array}{l}\text { Mandates both the } \\
\text { promisee } \\
\text { (contractor) and the } \\
\text { acceptor (employer) } \\
\text { to follow the sepcial } \\
\text { conditions of } \\
\text { liability mentioned } \\
\text { in the contract - The }\end{array}$ & $\begin{array}{l}\text { AI systems are } \\
\text { not considered }\end{array}$ \\
\hline
\end{tabular}




\begin{tabular}{|c|c|c|c|c|c|c|c|}
\hline & $\begin{array}{c}\text { and accidents } \\
\text { - Liability } \\
\text { issue }\end{array}$ & & & & & $\begin{array}{c}\text { usual form of } \\
\text { contract agreement } \\
\text { is FIDIC Yellow }\end{array}$ & \\
\hline 11 & $\begin{array}{c}\text { The liability } \\
\text { issue } \\
\text { regarding } \\
\text { hiring the } \\
\text { wrong labour } \\
\text { force and } \\
\text { creating the } \\
\text { delay }\end{array}$ & RI-7 & $\begin{array}{c}\text { Middle } \\
\text { Managers,Proj } \\
\text { ect Decision } \\
\text { Makers, } \\
\text { Organizational } \\
\text { Decision } \\
\text { Makers and } \\
\text { Community }\end{array}$ & & & Book & \\
\hline \multicolumn{8}{|c|}{ Ethical issues and risks in worker surveillance using AI systems } \\
\hline 12 & $\begin{array}{c}\text { Replacement } \\
\text { of incentive } \\
\text { based control } \\
\text { - construction } \\
\text { personnel } \\
\text { unaware of } \\
\text { the } \\
\text { monitoring } \\
\text { process }\end{array}$ & RI-8 & Specialists & $\begin{array}{c}\text { Industrial } \\
\text { Disputes Act } \\
1947 \mathrm{u} / \mathrm{s} 9 \mathrm{~A} \\
\text { and 9B }\end{array}$ & $\begin{array}{c}\text { The employer } \\
\text { needs to give a } \\
\text { notice to the } \\
\text { workers } 21 \text { days } \\
\text { before he } \\
\text { contemplates } \\
\text { implementing } \\
\text { change in the } \\
\text { hours of work, }\end{array}$ & $\begin{array}{l}\text { Workers informed in } \\
\text { advance regarding } \\
\text { their working hours }\end{array}$ & $\begin{array}{c}\text { Implemented on } \\
\text { a macro-level, } \\
\text { not on a site } \\
\text { level or activity } \\
\text { level. }\end{array}$ \\
\hline
\end{tabular}




\begin{tabular}{|c|c|c|c|c|c|c|c|}
\hline & $\begin{array}{c}\text { (worker } \\
\text { exploitation) }\end{array}$ & & & & $\begin{array}{c}\text { rest intervals, } \\
\text { wages etc. }\end{array}$ & & \\
\hline 13 & $\begin{array}{c}\text { Impact on } \\
\text { worker's right } \\
\text { of "work hard } \\
\text { to earn more" }\end{array}$ & RI-9 & $\begin{array}{c}\text { Specialists and } \\
\text { Community }\end{array}$ & & & & \\
\hline 14 & $\begin{array}{l}\text { Exploitation } \\
\text { and } \\
\text { infringement } \\
\text { of privacy of } \\
\text { managers } \\
\text { through } \\
\text { behavioural } \\
\text { analysis } \\
\text { using NLP } \\
\text { and such } \\
\text { techniques }\end{array}$ & RI-10 & $\begin{array}{c}\text { Middle } \\
\text { Managers, } \\
\text { Project } \\
\text { Decision } \\
\text { Makers and } \\
\text { Organizational } \\
\text { Decision } \\
\text { Makers }\end{array}$ & $\begin{array}{c}\text { IT Act } 2008- \\
\text { u/s 72A }\end{array}$ & $\begin{array}{c}\text { Prevent the } \\
\text { employee from } \\
\text { sharing the data } \\
\text { without the } \\
\text { consent of the } \\
\text { employee }\end{array}$ & $\begin{array}{l}\text { Prevent the transfer } \\
\text { of personal } \\
\text { information data of } \\
\text { the existing } \\
\text { employee without } \\
\text { the consent of the } \\
\text { employee to a third } \\
\text { party (monitoring } \\
\text { agency) causing } \\
\text { harm to the } \\
\text { employee }\end{array}$ & $\begin{array}{l}\text { Doesnot prevents } \\
\text { the usage of data } \\
\text { by the employer } \\
\text { HRD or using } \\
\text { them to nudge } \\
\text { the construction } \\
\text { personnel }\end{array}$ \\
\hline
\end{tabular}




\begin{tabular}{|c|c|c|c|c|c|c|c|}
\hline 15 & Digital Risk & RI-11 & $\begin{array}{l}\text { Client and } \\
\text { Community }\end{array}$ & $\begin{array}{c}\text { IT Act } 2008- \\
\text { u/s } 43\end{array}$ & $\begin{array}{l}\text { Compensation for } \\
\text { "Extracting } \\
\text { information from } \\
\text { a network or } \\
\text { database without } \\
\text { the permission of } \\
\text { the owner" }\end{array}$ & $\begin{array}{c}\text { Prevents the } \\
\text { unauthorized } \\
\text { extraction of data or } \\
\text { hacking of the } \\
\text { system through } \\
\text { imposing } \\
\text { compensation }\end{array}$ & $\begin{array}{l}\text { Doesnot mention } \\
\text { regarding the } \\
\text { security } \\
\text { requirements of } \\
\text { the collaborative } \\
\text { platform or } \\
\text { database }\end{array}$ \\
\hline 16 & $\begin{array}{l}\text { Liability } \\
\text { issues } \\
\text { regarding the } \\
\text { confidentialit } \\
\text { y of data }\end{array}$ & RI-12 & $\begin{array}{c}\text { Supervisors,Mi } \\
\text { ddle } \\
\text { Managers,Proj } \\
\text { ect Decision } \\
\text { Makers,Organi } \\
\text { zational } \\
\text { Decision } \\
\text { Makers and } \\
\text { Client }\end{array}$ & $\begin{array}{c}\text { IT Act } 2008- \\
\text { u/s 43A }\end{array}$ & $\begin{array}{l}\text { The body } \\
\text { corporate who } \\
\text { handles data is } \\
\text { liable for the } \\
\text { "Compensation } \\
\text { for negligence in } \\
\text { implementing and } \\
\text { maintaining } \\
\text { reasonable } \\
\text { security practices } \\
\text { and procedures in } \\
\text { handling the data } \\
\text { leading to } \\
\text { wrongful loss or }\end{array}$ & $\begin{array}{l}\text { Prevent the } \\
\text { negligence of data } \\
\text { handling by the } \\
\text { employer }\end{array}$ & $\begin{array}{l}\text { Doesnot consider } \\
\text { other } \\
\text { stakeholders who } \\
\text { are in the } \\
\text { "colaborative } \\
\text { decision making" }\end{array}$ \\
\hline
\end{tabular}




\begin{tabular}{|c|c|c|c|c|c|c|c|}
\hline & & & & & $\begin{array}{l}\text { wrongful gain to } \\
\text { any person" }\end{array}$ & & \\
\hline 17 & $\begin{array}{l}\text { The liability } \\
\text { puzzle - "if } \\
\text { the system } \\
\text { suggests a } \\
\text { decision and } \\
\text { the project } \\
\text { delays who is } \\
\text { going to be } \\
\text { accountable" }\end{array}$ & RI-13 & $\begin{array}{c}\text { Middle } \\
\text { Managers,Proj } \\
\text { ect Decision } \\
\text { Makers,Organi } \\
\text { zational } \\
\text { Decision } \\
\text { Makers and } \\
\text { Client }\end{array}$ & $\begin{array}{c}\text { Indian } \\
\text { Contracts Act } \\
1872\end{array}$ & $\begin{array}{l}\text { Entitles the party } \\
\text { to follow the } \\
\text { contracts (the } \\
\text { sepcial conditions } \\
\text { of liability } \\
\text { mentioned in the } \\
\text { contract) }\end{array}$ & $\begin{array}{l}\text { Mandates both the } \\
\text { promisee } \\
\text { (contractor) and the } \\
\text { acceptor (employer) } \\
\text { to follow the sepcial } \\
\text { conditions of } \\
\text { liability mentioned } \\
\text { in the contract - The } \\
\text { usual form of } \\
\text { contract agreement } \\
\text { is FIDIC Yellow } \\
\text { Book }\end{array}$ & $\begin{array}{l}\text { Need to explicitly } \\
\text { mention the } \\
\text { stakeholders of } \\
\text { the various work } \\
\text { packages in the } \\
\text { contract } \\
\text { agreement to } \\
\text { make them liable } \\
\text { for the } \\
\text { confidentiality of } \\
\text { the information }\end{array}$ \\
\hline \multicolumn{8}{|c|}{ Risks related to real-time tracking and ensuring safety and Quality } \\
\hline 18 & $\begin{array}{l}\text { Accidents in } \\
\text { the } \\
\text { construction } \\
\text { sites having }\end{array}$ & RI-14 & $\begin{array}{c}\text { All Except } \\
\text { Organizational } \\
\text { Decision } \\
\text { Makers }\end{array}$ & $\begin{array}{c}\text { Employees' } \\
\text { State } \\
\text { Insurance Act }\end{array}$ & $\begin{array}{l}\text { Insurance for the } \\
\text { employees against } \\
\text { accidents, } \\
\text { occupational }\end{array}$ & $\begin{array}{l}\text { Compensation for } \\
\text { accidents }\end{array}$ & $\begin{array}{c}\text { Only for } \\
\text { employees who } \\
\text { are drawing }\end{array}$ \\
\hline
\end{tabular}




\begin{tabular}{|c|c|c|c|c|c|c|c|}
\hline & $\begin{array}{c}\text { the AI safety } \\
\text { systems }\end{array}$ & & & $\begin{array}{c}-1948 \mathrm{u} / \mathrm{s} 38 \\
\text { and } 39\end{array}$ & $\begin{array}{l}\text { diseases in the } \\
\text { course of his / her } \\
\text { employment - } \\
\text { through the } \\
\text { employee and } \\
\text { employer } \\
\text { contribution }\end{array}$ & & $\begin{array}{l}\text { wages upto INR } \\
15000 \text { per month }\end{array}$ \\
\hline 19 & & & & $\begin{array}{l}\text { BOCW Act- } \\
1996-\mathrm{u} / \mathrm{s} 45\end{array}$ & $\begin{array}{l}\text { Responsibility of } \\
\text { compensation by } \\
\text { the contractor and } \\
\text { the employer }\end{array}$ & & $\begin{array}{l}\text { Doesnot include } \\
\text { managers or } \\
\text { supervisors who } \\
\text { are also victims } \\
\text { of accidents }\end{array}$ \\
\hline 20 & $\begin{array}{l}\text { Responsibilit } \\
\text { y of the } \\
\text { accident in } \\
\text { construction } \\
\text { sites having } \\
\text { the AI safety } \\
\text { systems }\end{array}$ & RI-15 & $\begin{array}{l}\text { Supervisors,Mi } \\
\text { ddle } \\
\text { Managers,Proj } \\
\text { ect Decision } \\
\text { Makers, Organi } \\
\text { zational } \\
\text { Decision } \\
\text { Makers and } \\
\text { Client }\end{array}$ & $\begin{array}{c}\text { Indian } \\
\text { Contracts Act } \\
1872\end{array}$ & $\begin{array}{l}\text { Entitles the party } \\
\text { to follow the } \\
\text { contracts (the } \\
\text { special conditions } \\
\text { of liability } \\
\text { mentioned in the } \\
\text { contract) }\end{array}$ & $\begin{array}{l}\text { Mandates both the } \\
\text { promisee } \\
\text { (contractor) and the } \\
\text { acceptor (employer) } \\
\text { to follow the special } \\
\text { conditions of } \\
\text { liability mentioned } \\
\text { in the contract - The } \\
\text { usual form of }\end{array}$ & $\begin{array}{l}\text { AI systems are } \\
\text { not considered or } \\
\text { held responsible. } \\
\text { In the contrract } \\
\text { agreement } \\
\text { usually the } \\
\text { contractor will } \\
\text { be liable for the } \\
\text { accidents. The }\end{array}$ \\
\hline
\end{tabular}




\begin{tabular}{|c|c|c|c|c|c|c|c|}
\hline & & & & & & $\begin{array}{c}\text { contract agreement } \\
\text { is FIDIC Yellow } \\
\text { Book }\end{array}$ & $\begin{array}{l}\text { principal } \\
\text { employer will } \\
\text { pay the }\end{array}$ \\
\hline 21 & & & & $\begin{array}{l}\text { BOCW Act- } \\
1996-\text { u/s } 44\end{array}$ & $\begin{array}{l}\text { Liability of the } \\
\text { employer to take } \\
\text { adequate steps to } \\
\text { prevent accidents }\end{array}$ & $\begin{array}{l}\text { Unless other wise } \\
\text { mentioned in the } \\
\text { contract agreement } \\
\text { the liability is with } \\
\text { the employer } \\
\text { (owner) }\end{array}$ & $\begin{array}{l}\text { per the ESI Act } \\
1948 \text { and then } \\
\text { recover the same } \\
\text { from the } \\
\text { contractor }\end{array}$ \\
\hline 22 & $\begin{array}{c}\text { Quality } \\
\text { related issues } \\
\text { in } \\
\text { construction } \\
\text { sites having } \\
\text { AI systems } \\
\text { for quality } \\
\text { assurance }\end{array}$ & RI - 16 & $\begin{array}{l}\text { Supervisors,Mi } \\
\text { ddle } \\
\text { Managers,Proj } \\
\text { ect Decision } \\
\text { Makers,Organi } \\
\text { zational } \\
\text { Decision } \\
\text { Makers and } \\
\text { Client }\end{array}$ & $\begin{array}{c}\text { Indian } \\
\text { Contracts Act } \\
1872\end{array}$ & $\begin{array}{l}\text { Entitles the party } \\
\text { to follow the } \\
\text { contracts (the } \\
\text { sepcial conditions } \\
\text { of liability } \\
\text { mentioned in the } \\
\text { contract) }\end{array}$ & $\begin{array}{l}\text { Mandates both the } \\
\text { promisee } \\
\text { (contractor) and the } \\
\text { acceptor (employer) } \\
\text { to follow the sepcial } \\
\text { conditions of } \\
\text { liability mentioned } \\
\text { in the contract - The } \\
\text { usual form of } \\
\text { contract agreement }\end{array}$ & \\
\hline
\end{tabular}




\begin{tabular}{|c|c|c|c|c|c|c|c|}
\hline & & & & & & $\begin{array}{c}\text { is FIDIC Yellow } \\
\text { Book }\end{array}$ & \\
\hline \multicolumn{8}{|c|}{ Accidents due to autonomous systems } \\
\hline 23 & $\begin{array}{l}\text { Accidents } \\
\text { due to } \\
\text { autonomous } \\
\text { systems }\end{array}$ & RI - 17 & $\begin{array}{c}\text { All Except } \\
\text { Organizational } \\
\text { Decision } \\
\text { Makers }\end{array}$ & $\begin{array}{c}\text { BOCW Act- } \\
1996-\mathrm{u} / \mathrm{s} 40 \\
\text { and } 47\end{array}$ & $\begin{array}{c}\text { "Penalty to } \\
\text { whoever } \\
\text { contravenes the } \\
\text { provisions } \\
\text { regarding the } \\
\text { safety measures" }\end{array}$ & $\begin{array}{c}\text { Ensuring safe work } \\
\text { environment }\end{array}$ & $\begin{array}{l}\text { AI systems are } \\
\text { not considered or } \\
\text { held responsible. } \\
\text { In the contrract } \\
\text { agreement } \\
\text { usually the }\end{array}$ \\
\hline 24 & $\begin{array}{l}\text { Liability } \\
\text { issues } \\
\text { regarding the } \\
\text { accident }\end{array}$ & RI - 18 & $\begin{array}{c}\text { Supervisors,Mi } \\
\text { ddle } \\
\text { Managers,Proj } \\
\text { ect Decision } \\
\text { Makers,Organi } \\
\text { zational } \\
\text { Decision } \\
\text { Makers and } \\
\text { Client }\end{array}$ & $\begin{array}{c}\text { Indian } \\
\text { Contracts Act } \\
1872\end{array}$ & $\begin{array}{l}\text { Entitles the party } \\
\text { to follow the } \\
\text { contracts (the } \\
\text { sepcial conditions } \\
\text { of liability } \\
\text { mentioned in the } \\
\text { contract) }\end{array}$ & $\begin{array}{l}\text { Mandates both the } \\
\text { promisee } \\
\text { (contractor) and the } \\
\text { acceptor (employer) } \\
\text { to follow the sepcial } \\
\text { conditions of } \\
\text { liability mentioned } \\
\text { in the contract - The } \\
\text { usual form of } \\
\text { contract agreement } \\
\text { is FIDIC Yellow } \\
\text { Book }\end{array}$ & $\begin{array}{l}\text { contractor will } \\
\text { be liable for the } \\
\text { accidents. The } \\
\text { principal } \\
\text { employer will } \\
\text { pay the } \\
\text { compensation as } \\
\text { per the ESI Act } \\
1948 \text { and then } \\
\text { recover the same } \\
\text { from the } \\
\text { contractor }\end{array}$ \\
\hline
\end{tabular}




\begin{tabular}{|l|l|l|l|c|c|}
\hline 25 & & & BOCW Act- \\
$1996-\mathrm{u} / \mathrm{s} 44$ & $\begin{array}{c}\text { Liability of the } \\
\text { employer to take } \\
\text { adequate steps to } \\
\text { prevent accidents }\end{array}$ & $\begin{array}{c}\text { Unless other wise } \\
\text { mentioned in the } \\
\text { contract agreement } \\
\text { the liability is with } \\
\text { the employer } \\
\text { (owner) }\end{array}$ \\
\hline
\end{tabular}




\subsection{Major Regulatory Gaps}

Over the years Government of India (GOI) has introduced many policies and acts to improve the livelihood of people who are below the poverty line. The frontline construction personnel (experts) who are the worker class fall under this category of people. The essential schemes introduced donot address the retrenchment or layoff of higher skilled employees such as site engineer and managers.

The inclusion of AI in the construction industry has introduced the requirement of a set of new regulations for safety on construction sites. The Building and Other Construction Workers (Regulation of Employment And Conditions of Service) Act ,1996 (BOCW Act 1996) and BOCW Rules - 1998 which are considered as the "rule book" for safety regulations on construction sites need to consider autonomous system different from other construction equipment. As per section 11 of BOCW Act 1996, the employer (or the owner or the client) is responsible for the testing, nomination and inspection of the construction equipment that is employed in the construction site (Building and Other Construction Workers (Regulation of Employment And Conditions of Service) Act 1996). These include cranes, wheel loaders, winches (and all those equipment) - their load test, periodic maintenance etc. FIDIC (International Federation of Consulting Engineers) contract, the most commonly used form of contracts, classify the construction equipment into 'employer's equipment' and 'contractor's equipment', and make the employer and the contractor responsible for their safety. Similarly, section 6 of BOCW 1996 makes the architect, project manager and designer responsible for the design of the buildings by due consideration to the safety aspects (Building and Other Construction Workers (Regulation of Employment And Conditions of Service) Act 
1996). There are duties and responsibilities of the workers for construction safety. This accountability system is sufficient for a normal construction site, but with the AI inclusion, there regulatory issues are more complex.

This can be better understood by the illustration of the accident of a self-drving car in Arizona in 2018 (Stilgoe 2018b, 2018a; Wakabayashi 2018), when the victim suddenly stepped in front of a moving autonomous car. Usually the liability of accidents is born by the drivers or pedestrians if the vehicles were working correctly. However, the presence of the AI system in the car created a new liability issue. The driver was not held responsible for the accident in Arizona. The failure of the prediction module was deemed to be the reason for the accident. Hence those involved in the design, manufacturing, testing and maintenance of the AI systems (Hayford 2014), were brought in to the liability spectrum.

Existing construction equipment is based on hydraulic mechanisms (or mechanical systems like gears and drives) with a handful of sensors. The construction personnel know the behaviour of this equipment, and can predict their movement. These are systems that can be dismantled and assembled without property change -complicated but not complex. Autonomous systems adapt to their surroundings, and are thus more complex. Such systems must be treated as a sperate entity in the construction site, like employers, contractors, workers etc. and should somehow be made accountable for the accidents or failures in the regulations. Major international standardss, such as ISO 12011:2010 (which provides guidance and framework for construction machinery design) are written to support designs that require human participation - but are not compatible with autonomous and learning construction systems. 


\section{Risk Tolerance and Regulatory Design to Fill Gaps}

From a policy perspective, regulatory strategy must also take into account societal risk tolerance. Risk tolerance, in this case, is the willingness of society to accept new risks that emerge from AI use in construction, even as existing risks may be reduced or eliminated. Risk tolerance is a function of the risk perception of society. Classical risk analysis (ISO 12100:2010(E) 2013) considers risk as a function of the probability of occurrence and the severity of harm. Such an analysis cannot be the sole consideration for designing regulations, as there is this assumption regarding the perception of indifference between low-consequence / high-probability risk and a high-consequence / low-probability risk by the society, which research has shown to be inaccurate (Kasperson et al. 1988; Slovic 2016). Formulating policy regulations without considering risk perception reduces the consensus among people regarding the new technology. This will lead to higher order costs to be borne by the industry and the Government due to social interactions and subsequent social consequences (Slovic 2016; Slovic et al. 1987). A small accident in an unfamiliar system creates larger social consequences than an accident that takes more lives (Slovic 2016; Slovic et al. 1987). This is due to the fear of "something bigger yet unknown" backed up by the plethora of history where emerging technologies lead to catastrophe.

The autonomous car accident at Arizona is a good example of the psychological risk perception and social consequences in AI. In Arizona, 2.74 persons were killed each day in 
2017 in car accidents, with little or no public call for changes to traffic regulation (The Arizona department of transportation 2018). Yet Uber faced great criticism and had to suspend their autonomous vehicle program due to the unfortunate accident that killed a pedestrian in March 2017 (Theo Legget 2018). Such accidents minimise the chance for the broad adoption of the technology and lead to indirect costs associated with stricter regulation, damaged reputation for the firm and the technology (Slovic 2016).

Construction risk falls into three categories: known risks, known unknowns and unknown unknowns (Jobling et al. 1999). Known risks are those that occur frequently (Jobling et al. 1999). For example, equipment break-down is a known risk. With known unknowns, we know either their frequency or impact (Jobling et al. 1999). The unknown unknowns are the forcemajeure (Jobling et al. 1999). There are provisions in the contract to account for the forcemajeure. The known-knowns and the known-unknowns are controllable, and the responsibility of the risk mitigation lies with the contractor.

With the advent of AI, many of the known-known risks become unknown-unknown. The construction contractor is not currently held responsible for accidents due to autonomous equipment, as they are not aware of the algorithms responsible. Even the AI developers are not accountable for their outcome due to the foreseeability issues of many of the algorithms (Scherer 2015). Hence, there is an entire shift of activities from the known space to the unknown space leading to the fear of "something bigger yet unknown".

Hence, we define the need for regulation ( $\mathrm{Rn}$ ) (as illustrated in Figure 8) as a function of the risks associated with AI inclusion and risk tolerance as Equation 1. As per ISO 12100:2010(E) 
the risk is the function of the probability of occurrence $(\mathrm{P})$ and the severity of the impact (I) (ISO 12100:2010(E) 2013). We include T as the risk tolerance.

$$
R_{n}=f(P, I, T)(\text { Equation - 1) }
$$

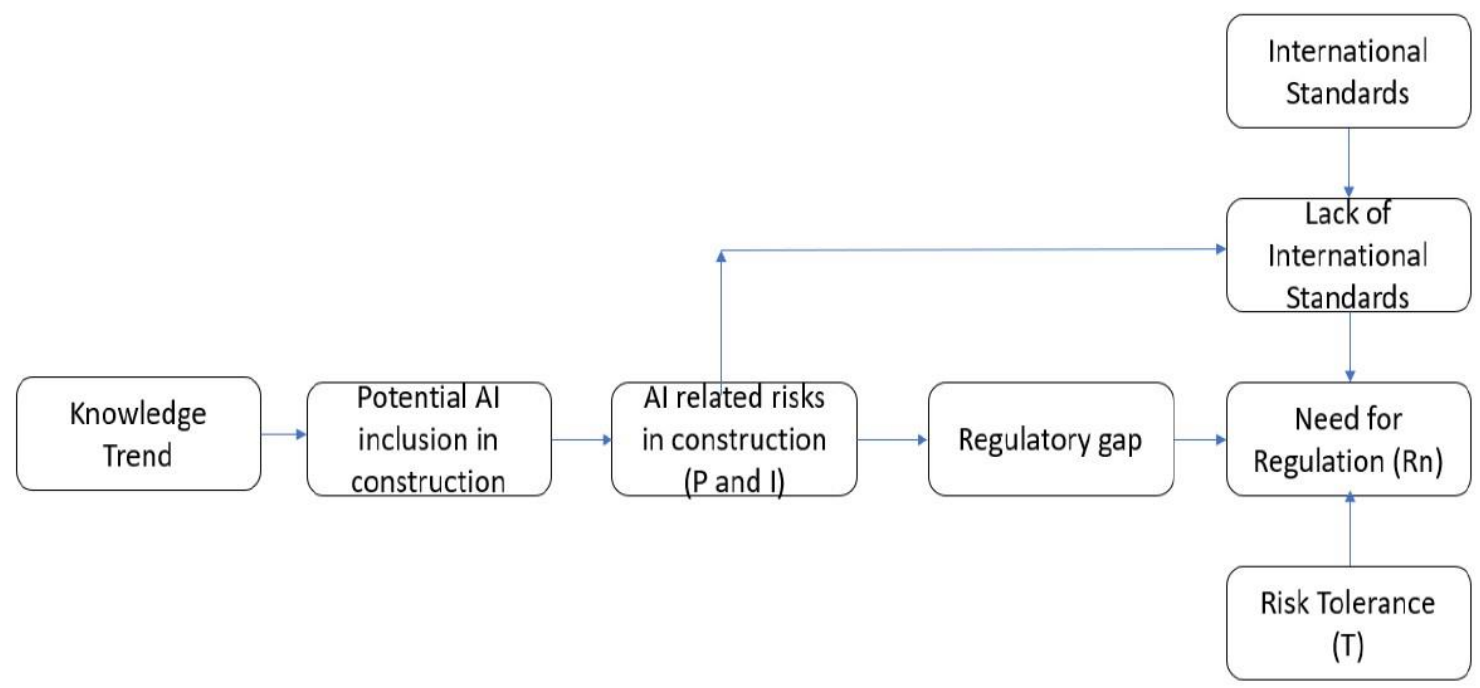

Figure 8: The "Need for Regulation"

Mathematical models and simulation tools are used to quantify the probability and impact of the risks (Larson \& Gray 2015). Future work is needed, via surveys and expert elicitation (Slovic 2016) to quantify theses risk tolerances to support future regulatory design.

\section{Conclusion}

Regulation of futuristic technologies such as AI is challenging as it is difficult to understand the risks associated with their inclusion due to the lack of tacit and applied knowledge. It is in this regard that we understand the thematic trends using publications by scholars in field of application. We anticipate the AI inclusion in construction and the potential risks considering 
the trajectory of automation happening in construction and other sectors. The risks are identified by considering the AI inclusion on the other sectors and their associated risks, the potential AI inclusion in various construction tasks and the effect of this inclusion on the victim groups.

We found that existing laws and regulations are not formulated for AI. AI brings in a new set of socio-political risks in the form of health and safety concern, liability issues and privacy infringement cases. The regulatory gaps are identified from these issues and the existing regulations in the Indian Construction Sector. Identification of regulatory gaps enables us to decouple the risk impacts from the AI inclusion and technological development in the construction sector to a certain extent. Design of regulations is based on the economic, social and political structure of the society. India is the second most populous country in the world and the focus currently is on the growing challenge of unemployment. Therefore, socioeconomic impact due to automation will be the prime concern regarding AI inclusion in construction. This along with the various methods adopted for hiring processes will lead to socio-political issues like unemployment, income inequality among particular communities and gender, ultimately leading to poverty and social unrest. The other significant concern is regarding safety consideration due to AI inclusion. For AI in construction, though it has the intention to reduce the construction-related accidents, we need to consider the potential risks that the AI adds to the overall safety of construction activities. These risks are not limited to errors and bias in the AI systems and privacy infringement. Amendments in the regulations considering these risks and regulatory gaps can decouple the risks to a large extent and support AI inclusion in the construction sector. 
We also show that the regulatory amendments need to consider psychological risk perceptions along with the inherent complexity of the AI technology, their potential inclusion and the inadequacy in regulations.

Finding the potential degree of probability and impact enables the regulators to quantify the risks. Future research should examine the implications of various regulatory options by weighing these quantified risks with the risk tolerance to design regulations in the field of AI inclusion in the construction sector.

\section{References}

Akhavian R, Behzadan AH (2016) Smartphone-based construction workers' activity recognition and classification Automation in Construction 71, 198-209.

Anadon LD, Chan G, Harley AG et al. (2016) Making technological innovation work for sustainable development. Proceedings of the National Academy of Sciences of the United States of America 113, 9682-9690.

Anumba CJ, Ugwu OO, Newnham L, Thorpe A (2002) Collaborative design of structures using intelligent agents Automation in Construction 11, 89-103.

Aria M, Cuccurullo C (2017) bibliometrix: An R-tool for comprehensive science mapping analysis Journal of Informetrics 11, 959-975.

Awad A, Fayek AR (2012) A decision support system for contractor prequalification for surety bonding Automation in Construction 21, 89-98.

BIM+ (2018) AI-based software for construction planning

Blanco J, Mullin A, Pandya K, Sridhar M (2017) The new age of engineering and construction technology

Boyes H, Luck A (2015) Digital risk: What BIM means for industry security | Analysis | 
Construction News Construction News pp. 1-5. Retrieved from https://www.constructionnews.co.uk/analysis/news-analysis/digital-risk-what-bimmeansfor-industry-security/8689780.article

Bryman A (2016) Social research methods Oxford university press.

Bughin J, Hazan E, Ramaswamy S et al. (2017) Artificial Intelligence - The Next Digital Frontier? In Artificial Intelligence,

Building and Other Construction Workers (Regulation of Employment And Conditions of Service) Act , (1996)

Chen K, Lu W, Peng Y, Rowlinson S, Huang GQ (2015) Bridging BIM and building: From a literature review to an integrated conceptual framework International Journal of Project Management 33, 1405-1416.

Cooke T, Lingard H, Blismas N, Stranieri A (2008) ToolSHeDTM: the development and evaluation of a decision support tool for health and safety in construction design Engineering, Construction and Architectural Management 15, 336-351.

Daniel Malan (2018) The law can't keep up with new tech. Here's how to close the gap Retrieved from World Economic Forum website: https://www.weforum.org/agenda/2018/06/law-too-slow-for-new-tech-how-keep-up/

Department for Business Innovation and Skills (2014) Estimating Innovation Spillovers: an International Sectoral and UK Enterprise Study

Eissfeller R (2001) (12) United States Patent

Feng C, Xiao Y, Willette A, Mcgee W, Kamat VR (2015) Automation in Construction Vision guided autonomous robotic assembly and as-built scanning on unstructured construction sites 59, 128-138.

Fruchterman TMJ, Reingold EM (1991) Graph drawing by force-directed placement Software: Practice and Experience 21, 1129-1164. 
Global Autonomous Construction Equipment Market Report 2018: Size, Market Share, Application Analysis, Regional Outlook, Growth Trends, Key Players, Competitive Strategies and Forecasts, 2016-2026 (2019, February 18) NASDAQ OMX's News

Release Distribution Channel. Retrieved from https://search.proquest.com/docview/2182475246? accountid=29018

Global Construction Market to Grow \$8 Trillion by 2030: Driven by China, US and India (2018, November 9) PR Newswire Europe Including UK Disclose. Retrieved from https://www.prnewswire.com/news-releases/global-construction-outlook-to2022300682433.html

Global Construction Outlook to 2022 (2018, July 17)

Golabchi A, Han SU, AbouRizk S, Kanerva J (2016) Micro-motion level simulation for efficiency analysis and duration estimation of manual operations Automation in Construction 71, 443-452.

Golparvar-Fard M, Peña-Mora F, Savarese S (2012) Automated progress monitoring using unordered daily construction photographs and IFC-based building information models Journal of Computing in Civil Engineering 29, 4014025.

Goodall N (2014) Ethical Decision Making During Automated Vehicle Crashes Transportation Research Record: Journal of the Transportation Research Board 2424, 58-65.

Griliches Z (1991) The search for $R \& D$ spillovers National Bureau of Economic Research.

Hanna AS, Iskandar KA, Lotfallah W, Ibrahim MW, Russell JS (2018) A data-driven approach for identifying project manager competency weights Canadian Journal of Civil Engineering 45, 1-8.

Hayford O (2014) Self-Driving Vehicles in Logistics 48-51.

Hong Y, Chan DWM, Chan APC, Yeung JFY (2011) Critical analysis of partnering research trend in construction journals Journal of Management in Engineering 28, 82-95. 
Hong Y, WM Chan D (2014) Research trend of joint ventures in construction: a two-decade taxonomic review Journal of Facilities Management 12, 118-141.

ISO 12100:2010(E) (2013) INTERNATIONAL STANDARD for design-Risk assessment and risk (Vol. 2010)

James Manyika, Michael Chui, Mehdi Miremadi , Jacques Bughin, Katy George, Paul Willmott MD (2017) A Future that Works: Automation, Employment and Productivity

Jobling P, Tony M, Smith NJ (1999) Managing Risk in Construction Projects

Kasperson RE, Renn O, Slovic P et al. (1988) The social amplification of risk: A conceptual framework Risk Analysis 8, 177-187.

Ke Y, Wang S, Chan AP, Cheung E (2009) Research trend of public-private partnership in construction journals Journal of Construction Engineering and Management 135, 10761086.

Kim C, Park T, Lim H, Kim H (2013) On-site construction management using mobile computing technology Automation in Construction 35, 415-423.

Laefer DF, Truong-Hong L (2017) Toward automatic generation of 3D steel structures for building information modelling Automation in Construction 74, 66-77.

Larson EW, Gray CF (2015) A Guide to the Project Management Body of Knowledge: PMBOK (®) Guide Project Management Institute.

Luo H, Xiong C, Fang W, Love PED, Zhang B, Ouyang X (2018) Convolutional neural networks: Computer vision-based workforce activity assessment in construction Automation in Construction 94, 282-289.

Mahatma Gandhi National Rural Employment Guarantee Act (MNREGA), (2005)

Mandel GN (2009) Regulating emerging technologies Law, Innovation and Technology 1, 75-92.

Matus KJM (2009) Green chemistry: A study of innovation for sustainable development 
(Harvard

University)

Retrieved

from https://search.proquest.com/docview/304891409?accountid=29018

Motawa I, Almarshad A (2013) A knowledge-based BIM system for building maintenance Automation in Construction 29, 173-182.

Navarro-Astor E, Román-Onsalo M, Infante-Perea M (2017) Women's career development in the construction industry across 15 years: main barriers Journal of Engineering, Design and Technology 15, 199-221.

NBS (2018) National BIM Report 2016 In National BIM Report 2016,

Osei-kyei R, Chan APC (2015) ScienceDirect Review of studies on the Critical Success Factors for Public - Private Partnership ( PPP ) projects from 1990 to 2013 International Journal of Project Management 33, 1335-1346.

Padalkar M, Gopinath S (2016) ScienceDirect Six decades of project management research : Thematic trends and future opportunities JPMA 34, 1305-1321.

Parveen R (2018) Article ID: IJCIET_09_13_096 Legal Issues and Regulatory Challenges International Journal of Civil Engineering and Technology (IJCIET) 9, 957-962. Retrieved from http://www.iaeme.com/IJCIET/index.asp957http://www.iaeme.com/ijciet/issues.asp?J Type=IJCIET \&VType=9\&IType=13http://www.iaeme.comhttp://www.iaeme.com/IJ CIET/index.asp958

Perrow C (2011) Normal Accidents: Living with High Risk Technologies-Updated Edition Princeton university press.

Polanyi M, Sen M (1966) The Tacit Dimension Retrieved from https://books.google.com.hk/books?id=YZFKngEACAAJ

Pomerol J (1997) Artificial intelligence and human decision making 2217.

PWC (2017) The Essential Eight technologies Board byte: augmented and virtual reality 9. Retrieved from https://www.pwc.com/us/en/governance-insights- 
center/publications/assets/essential-emerging-technologies-augmented-andvirtualreality.pdf

Schellekens M (2015) Self-driving cars and the chilling effect of liability law Computer Law and Security Review 31, 506-517.

Scherer MU (2015) Regulating Artificial Intelligence Systems: Risks, Challenges, Competencies, and Strategies Ssrn 29.

Seo J, Lee S, Kim J, Kim S-K (2011) Task planner design for an automated excavation system Automation in Construction 20, 954-966.

Shen W-M, Simon HA (1994) Autonomous learning from the environment WH Freeman and Company Citeseer.

Sklar J (2015) Robots Lay Three Times as Many Bricks as Construction Workers MIT $\begin{array}{llll}\text { Technology Review. } & \text { Retrieved }\end{array}$ https://www.technologyreview.com/s/540916/robots-lay-three-times-as-many-bricksasconstruction-workers/\#

Slovic P (2016) The perception of risk Routledge.

Slovic P, MacGregor D, Kraus NN (1987) Perception of risk from automobile safety defects Accident Analysis \& Prevention 19, 359-373.

Sodhi P, Awasthi N, Sharma V (2019) Introduction to Machine Learning and Its Basic Application in Python Available at SSRN 3323796.

Solon S, Labor SI, Ai T, ... Ai E (2017) AI Now 2017 Report

Stilgoe J (2018a) Machine learning, social learning and the governance of self-driving cars Social Studies of Science 48, 25-56.

Stilgoe J (2018b) We Need New Rules for Self-Driving Cars. Issues in Science \& Technology 34, $52 . \quad$ Retrieved from http://search.ebscohost.com/login.aspx?direct=true $\& d b=u l h \& A N=129399641$ 
Su H-N, Lee P-C (2010) Mapping knowledge structure by keyword co-occurrence: a first look at journal papers in Technology Foresight Scientometrics 85, 65-79.

Summits P, Visits S, Luis J, Partner B (2018) Artificial intelligence : Construction technology' s next frontier $1-7$.

The Arizona department of transportation (2018) 2017 Motor Vehicle Crash Facts for the State of Arizona

Theo Legget (2018) Who is to blame for "self-driving car" deaths? BBC News. Retrieved from https://www.bbc.com/news/business-44159581

Volk R, Stengel J, Schultmann F (2014) Building Information Modeling (BIM) for existing buildings_-Literature review and future needs Automation in Construction 38, 109- 127.

Wakabayashi D (2018) Self-Driving Uber Car Kills Pedestrian in Arizona, Where Robots Roam New York Times 1-4.

Wall T, Journal S, York N, York NYN, Mar NYR (2017) Workplace Technology ( A Special Report ) --- How AI Is Transforming the Workplace : Artificial intelligence is changing the way managers do their job -- from who gets hired to how they 're evaluated to who gets promoted; but is it too intrusive? And c pp. 1-7.

Whittaker M (2018) AI Now Report 2018 Retrieved from www.ainowinstitute.org

Wu W, Yang H, Chew DAS, Yang S hua, Gibb AGF, Li Q (2010) Towards an autonomous real-time tracking system of near-miss accidents on construction sites Automation in Construction 19, 134-141.

Yin X, Liu H, Chen Y, Al-Hussein M (2019) Building information modelling for off-site construction: Review and future directions Automation in Construction 101, 72-91.

You S, Kim J-H, Lee S, Kamat V, Robert Jr LP (2018) Enhancing perceived safety in humanrobot collaborative construction using immersive virtual environments Automation in Construction 96, 161-170. 
Zhang J, Yu Q, Zheng F, Long C, Lu Z, Duan Z (2016) Comparing keywords plus of WOS and author keywords: A case study of patient adherence research Journal of the Association for Information Science and Technology 67, 967-972.

Zou PXW, Sunindijo RY, Dainty ARJ (2014) A mixed methods research design for bridging the gap between research and practice in construction safety Safety Science 70, 316-326.

\section{Laws Cited}

Mahatma Gandhi National Rural Employment Guarantee Act (MNREGA) 2005

Establishment of Regional Rural Banks (RRB) Act 1976

Ministry of Micro, Small and Medium Enterprises (MSME) Act 2006

Minimum Wages Act 1948

Industrial et al. 1947

IT Act 2008

Indian Contracts Act 1872

Employees' State Insurance Act 1948

Building and Other Construction Workers (Regulation of Employment And Conditions of Service) Act 1996

Building and Other Construction Workers (Regulation of Employment And Conditions of Service) Rules 1998 
